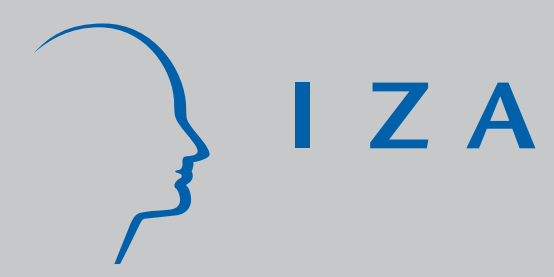

IZA DP No. 3872

Charitable Giving for Overseas Development: UK Trends over a Quarter Century

Anthony B. Atkinson

Peter G. Backus

J ohn Micklewright

Cathy Pharoah

Sylke V. Schnepf

December 2008 


\title{
Charitable Giving for Overseas Development: UK Trends over a Quarter Century
}

\author{
Anthony B. Atkinson \\ University of Oxford \\ Peter G. Backus \\ University of Southampton \\ and University of Warwick
}

John Micklewright

University of Southampton and IZA

\section{Cathy Pharoah \\ City University London}

\author{
Sylke V. Schnepf \\ University of Southampton and IZA
}
Discussion Paper No. 3872
December 2008

\author{
IZA \\ P.O. Box 7240 \\ 53072 Bonn \\ Germany \\ Phone: $+49-228-3894-0$ \\ Fax: +49-228-3894-180 \\ E-mail: iza@iza.org
}

\begin{abstract}
Any opinions expressed here are those of the author(s) and not those of IZA. Research published in this series may include views on policy, but the institute itself takes no institutional policy positions.

The Institute for the Study of Labor (IZA) in Bonn is a local and virtual international research center and a place of communication between science, politics and business. IZA is an independent nonprofit organization supported by Deutsche Post World Net. The center is associated with the University of Bonn and offers a stimulating research environment through its international network, workshops and conferences, data service, project support, research visits and doctoral program. IZA engages in (i) original and internationally competitive research in all fields of labor economics, (ii) development of policy concepts, and (iii) dissemination of research results and concepts to the interested public.
\end{abstract}

IZA Discussion Papers often represent preliminary work and are circulated to encourage discussion. Citation of such a paper should account for its provisional character. A revised version may be available directly from the author. 


\section{ABSTRACT \\ Charitable Giving for Overseas Development: UK Trends over a Quarter Century}

Charitable giving for overseas development and emergency relief is important in the UK, being about a quarter of the size of government development aid. There has been a strong growth over time, reflecting the activities of development charities and the public response to a series of humanitarian emergencies. This paper examines how individual overseas giving has changed over the quarter century since 1978, using a newly constructed panel data set on donations to individual UK charities. When did the increase take place? Did the public respond to events such as Live Aid? Or has there been a steady upward trend as our society became more globalised? What form did the increase in giving take? Which charities have grown fastest? Have new charities displaced old? How do changes in giving for overseas compare with changes in giving for other causes such as cancer relief or animal welfare? What, if any, is the relation with Official Development Assistance?

JEL Classification: D12, D64, F35, L31

Keywords: charitable giving, overseas development, philanthropy, UK

Corresponding author:

John Micklewright

School of Social Sciences

University of Southampton

Southampton

SO17 1BJ

United Kingdom

E-mail: jm4@soton.ac.uk

\footnotetext{
* This research was supported by ESRC project grant 'Giving to Development' (RES-155-25-0061), which forms part of the Non-Governmental Public Action programme. We are most grateful to the Charities Aid Foundation for allowing access to their data; data from Charity Trends from 2001 onwards are used also with permission of Waterlow Ltd. We thank lan Mocroft for much help in documenting government funding of development charities, Joe Cannon for supplying the Band Aid Trust's accounts from the 1980s, Eleanor Tew of the Charity Commission for providing information on charity name changes, Oxfam for access to its library, and Priya Khambhaita for research assistance.
} 


\section{Introduction}

The UK's Official Development Assistance (ODA), the money given by the government for emergency relief and long-term development in developing countries, stagnated in real terms during the 1980s and 1990s - see Figure 1 - and fell as a percentage of national income. This changed after 1997, reflecting New Labour's commitment to overseas development. ODA almost doubled in real terms over 20006 , rising to 0.5 per cent of national income, and the Labour government is committed to achieving the UN target of 0.7 per cent by 2013.

This is the government's record, but what has been done by individual UK citizens? Charitable donations by individuals for overseas development are the focus of this paper. These donations are important for at least three reasons. They are a signal of the concerns of UK citizens; there is currently a great deal of interest in the role of the third sector; and private giving is quantitatively a significant part of the picture. The largest charities focusing on overseas development and emergency relief received nearly $£ 1$ billion in 'voluntary income’ in 2004-5, equal to about a quarter of the figure for ODA in that year. In this paper, we examine the trends in individual overseas giving over the period 1978-2004 and how private giving for overseas development has changed against the backdrop of the trends in official giving.

The broad picture is well known: private giving in the UK for overseas development has increased substantially. Well established NGOs such as Oxfam and Save the Children have greatly expanded their activities. New charities such as WaterAid (created in 1981) have demonstrated innovative ways of tackling old problems. There has been a strong public response to a series of humanitarian emergencies. Popular sentiment was captured by events such as the Band Aid Christmas single in 1984 and the Live Aid concerts of the following year, both devoted to raising funds for famine relief in Ethiopia. More recently there has been the remarkable response to the 2004 Asian Tsunami, and the longer term development needs of poor countries have been highlighted by the Live 8 concerts of 2005 and by the Make Poverty History campaign. Prominent new fund-raising charities have sprung up which reach out to mass television audiences, such as Comic Relief that organises Red Nose Day and Sport Relief.

But just how much has private overseas giving increased? When did the increase take place? Was it largely a response to events such as Band Aid and Live 8? 
Or has there been a steady upward trend? What form did the increase in giving take? Which charities have grown fastest? Have new charities displaced old? How does giving for overseas compare with giving for other causes such as cancer relief or animal welfare? What, if any, is the relation with ODA? These are the questions that we address.

The first section (Section 2) describes the construction of the new panel data set on individual UK charities used in the paper. The underlying data are drawn from the long-standing annual publication Charity Trends (earlier Charity Statistics before 1986 and Dimensions of the Voluntary Sector from 1994 to 2002), and have considerable advantages: they represent the population of larger fundraising charities, rather than a sample, and they are the only (compiled) source of information on the voluntary donated income of charities in the UK that covers the 25 years period with which we are concerned. ${ }^{1}$ From these data made available by the Charities Aid Foundation (CAF), we have constructed a new panel data set covering the incomes of individual charities. Construction of the data set involves a number of problems, and the data have to be adjusted to increase the degree of consistency over time. Since we believe these data construction aspects to be important, we have devoted space in the paper to explaining the approach taken. In addition, the Appendix gives more detail about the way in which we have assembled information from each year's publication. (Pharoah, forthcoming, summarises the history of Charity Trends.)

The panel data set allows us to examine the size and rank of individual development charities over the period since 1978. In Section 3 we document the rise in the number of development charities covered by our data and in their representation in the top 200, and the next 200, of all UK charities. In Section 4 we examine the growth in the total donations received by the top development charities as a whole over the quarter century. We investigate whether there has been a steady rise in giving or whether it has come in the form of discrete shifts at different points in time, stimulated perhaps by such events as Live Aid.

Behind the total amounts lie the experiences of individual development charities. What was happening to UNICEF, to Tearfund and to War on Want? In

\footnotetext{
${ }^{1}$ The Charity Commission holds copies of the annual accounts of all registered charities in England and Wales, but the accounts are readily available only for recent years. The annual analysis of the top 3,000 charities by CaritasData is now in its $16^{\text {th }}$ year (CaritasData 2008) but this source would provide coverage for substantially fewer years than does Charity Trends. See also Charity Market Monitor 2008, (Pharoah 2008), the first of a new annual publication on the top 300 fund-raising charities.
} 
Section 5, we examine the history of giving to individual charities. How fast did they grow? How many of the top development charities in 1978 were still there in 2004? Has growth come more from long-standing charities or from new charities founded since the end of the 1970s? Has the concentration of 'market share' of the larger development charities changed?

To this point, we have focused on giving for overseas development, but in Section 6 we make a comparison with giving to other causes. Have trends in giving for development differed markedly from those for other causes, such as cancer relief, animal welfare, children etc? If not, this may call into question any simple explanation for the large rises in giving for overseas causes in terms of growing awareness of need in the developing world or the impact of humanitarian emergencies.

We began with Official Development Assistance (ODA). In Section 7, we return to the relation between charitable giving and ODA. This relationship is complicated by the fact that the totals for ODA include grants made by the government to UK development charities, and these turn out to have expanded significantly over the period we study. Section 8 summarises the main conclusions.

Figure 1 near here.

\section{Constructing a panel of data on the incomes of charities}

The data used in this paper originate in the series of annual surveys of the finances of major UK charities initiated by the Charities Aid Foundation (CAF) in 1977. We use the CAF files for the reports from 1978 to 2006. Up until 2001, CAF itself collected the data, in part through direct contact with charities. From 2001, all data were supplied to CAF by CaritasData, who became the co-publisher of the report, although for brevity we refer throughout to "the CAF data".

The CAF data cover a wide range of charities; and indeed the coverage has been extended with the 2004 report. $^{2}$ Here we are specifically concerned with development charities. Table 1 lists the 16 charities in the UK reported in Charity

\footnotetext{
${ }^{2}$ Prior to the 2004 report, CAF excluded many organisations that were formal charities but which were essentially single-interest bodies working for their own institutions or very narrowly-focussed beneficiary groups (for example church diocesan trusts). In our analysis, charities that enter the report for the first time in 2004 or subsequently are excluded so as to ensure consistency over time. (For the same reason, we do not use data from the 2007 report since the definition of voluntary income changed in that year to include government grants.)
} 
Trends 2006 as raising more than $£ 10$ million in voluntary income that had a principal focus on overseas development and relief. Throughout our analysis of the CAF data, we include under "development" both the charities grouped under this heading in the CAF reports (with the exception of the Priory of St John, commonly known as St John Ambulance) and the 'religious international' charities that are separately identified by CAF (e.g. CAF 2004: Figure 2.4), which include Christian Aid, CAFOD, and Islamic Relief.

The 16 top development charities shown in Table 1 include many well-known names such as Oxfam, Save the Children, and the Red Cross. They also include some newer entrants such as World Emergency Relief and WaterAid. The definition of 'voluntary income', to which we return below, includes both gifts and legacies. The total $£ 3 / 4$ billion raised by these 16 charities represents the bulk of all voluntary income received by UK development charities. It also represents the charities' main source of income - overseas development charities depend more heavily on their voluntary income than do most other types of charity, excluding faith-based organisations (CAF 2004: 87).

A number of features of the overseas development charities sector are immediately clear from Table 1 . First, while all the charities have a focus on development and/or emergency relief, their particular aims or organisational ties vary markedly, as is obvious in some cases from just an inspection of their names. There are what might be called general purpose charities, such as Oxfam and ActionAid. There are charities that have similar aims but with a religious link, such as Christian Aid, CAFOD, and Islamic Relief. There are charities focusing on particular groups in the population, children in the case of Save the Children and UNICEF, and the blind and those threatened by blindness in the case of Sight Savers, or particular issues, for example WaterAid. And while most of the charities in the list work solely in developing countries, others also have significant domestic programmes within the UK, which implies that their donations cannot be seen as being given only for overseas development causes. The Red Cross and Comic Relief are examples. This heterogeneity suggests there may be shifts within the sector over time as particular causes gain or lose popularity.

Second, these 16 largest fundraisers vary enormously in the level of donations that they attract. More than a half of the total went to the largest four charities. The largest are raising sums that place them high in the CAF ranking of all charities. The 
smaller ones collect amounts that place them far lower, although it is notable that they are all still among the top fundraising charities (the lowest is Médecins Sans Frontières ranked by CAF as 103rd).

Third, the table reflects some of the changes that have taken place within the overseas sector over the last 25 years. We indicate whether the charity concerned was also among the top 200 fundraising charities in 1978 and the year in which the charity was founded. Six of the charities were in the top 200 of the equivalent CAF table for 1978. Of these, some were relatively recently established, such as ActionAid, but others had longer histories, with the Red Cross stretching back well into the nineteenth century. Of those that were not in the top 200 in 1978, in four cases they have been founded subsequently, for example Islamic Relief. These differing dynamics are a major reason for the interest in constructing a panel for individual charities.

Table 1 near here

\section{Constructing a panel of data on charitable income}

CAF's Charity Trends began in 1978. Throughout their existence the annual reports have aimed to document the 'voluntary incomes', other incomes (e.g. government funding, trading), and selected expenditures of the leading fundraising charities in the UK. Initially, the target coverage was the top 200 fundraising charities, the planned coverage increasing to the top 300 in 1985, to the top 400 in 1986, and to the top 500 since 1991. (These dates refer to the year of publication.) We use the CAF files for the reports from 1978 to 2006 (there was no report in 1995, and we did not have access to the report for 1981).

The 500 charities now covered by the CAF data represent less than half of one per cent of the more than 160,000 active charities in the UK. However, most charities are very small. In 2007/08, only 5,549 had an income from all sources (not just voluntary income) of over $£ 1$ million and half of all income went to the 706 largest charities. ${ }^{3}$ CAF estimate that the top 1,000 fundraising charities account for just over a half of all voluntary income, with the top 500 raising almost 90 per cent of this (CAF 2004: ix, 21, 40). In recent years the CAF data have included about 30 overseas development charities. In the case of overseas development, we believe that the CAF

\footnotetext{
${ }^{3}$ http://www.charity-commission.gov.uk/registeredcharities/factfigures.asp
} 
top 500 coverage is even higher as a proportion, since some economies of scale are needed to operate effectively overseas.

To assemble a panel data set on donation income, we need information (a) covering a long run of years, (b) providing data on individual charities on a consistent basis, and (c) giving figures on donations received. While there are certain problems, discussed below, the CAF annual reports can be used to construct a panel meeting these three requirements. Indeed, in our view, the CAF data represent a rich source of panel information that has to date been insufficiently exploited. ${ }^{4}$ The $25^{\text {th }}$ Anniversary edition of Charity Trends, for example, analysed developments over the previous quarter century but focused on causes rather than individual charities. In what follows, we describe the construction of the panel used here.

The CAF reports rank charities by their total 'voluntary income'. This is defined by CAF to include (a) donations from individual donors, companies, and other charitable trusts, voluntary subscriptions, (b) legacies, (c) the value of goods donated to charity shops, (d) the revenue from fundraising events, and (e) National Lottery fund grants (after 1995). Table 2 provides a breakdown of the total voluntary income across these categories from Charity Trends 2003, distinguishing between development and other charities. Around half of voluntary income comes from donations. For other causes, legacies make up a further 30 per cent, but for development charities legacies are much less important (12 per cent).

Donations come largely from individuals, but also include those from the corporate sector and from grant-making charitable trusts. These cannot be separated in the data employed here, but recent estimates based on the breakdown for the top 300 charities (serving all causes) in the Charity Market Monitor 2008 indicate that corporate donations represent about 1 per cent of total voluntary income and trusts about 8 per cent (Pharoah 2008: 63). ${ }^{5}$ The private donations figure reported in any one year in principle includes the value of basic rate tax relief that charities claim on donations which have been made with a Gift Aid declaration (from 1990 for gifts of $£ 600$ or more and from 2000 for all amounts), and the value of tax relief of donations

\footnotetext{
${ }^{4}$ Robinson (1993) uses CAF data to track the growth in aid charities' total income from 1977-1991, but, to our knowledge, the CAF data have only once before been assembled with the aim of tracing individual charities across the years. Khanna et al (1995) and Khanna and Sandler (2000) estimate econometric models with data for 1983-90, but do not focus in particular on international development charities.

${ }^{5}$ Funds received from trusts were particularly important for Christian Aid (38 per cent of fund-raised income) and CAFOD (46 per cent) (Pharoah 2008: 65).
} 
by covenant, which were very important until phased out in 2000, to be replaced (in some cases with a time lag) by Gift Aid. The figure for donated goods to charity shops is dominated in the case of the development charities by the total for one charity, Oxfam, for which the 2003 report lists a total of $£ 53$ million - over 40 per cent of Oxfam's total voluntary income. Only two other development charities, the Red Cross and Save the Children, have non-trivial totals listed under this heading (representing about 30 per cent and 10 per cent of their total voluntary incomes respectively), although other charities do have charity shops. We discuss later the changes that have taken place in the definition of shop income.

Table 2 near here

Several development charities give significant sums of money that they have raised to other UK development charities, especially if they perform what is essentially a 'middleman' role in fundraising. The money concerned is then reported by the receiving charities as part of their voluntary income, implying that there may be some double counting of the sector total if both donor and recipient are in the CAF rankings. Christian Aid, Comic Relief, Oxfam, CAFOD, and Tearfund are examples of 'grant-making' donor charities (CAF 2004: 97). (The CAF data do not record the charities to which the grants were made.) Charities are listed above in descending order of the size of grants made, which ranged from $£ 36$ million to $£ 16$ million. These amounts are significant but not large in relation to the sector total. On balance, we think the double-counting problem to be minor. Band Aid Trust, which was prominent in the 1980s, is another example of a grant-making charity, and we return to this particular case later. ${ }^{6}$

In creating a panel, there are a number of aspects that require adjustments to the data, of which the most important are described below (the Appendix gives further details):

Assignment of data to years. As Table 1 illustrates, there may be considerable variation from charity to charity in the 12 month period covered by the data in any one annual CAF charities’ report. Since we wish to carry out a time series analysis,

\footnotetext{
${ }^{6}$ The Disasters Emergency Committee (DEC) is a pure 'middleman' development charity. This is an umbrella grouping of major development charities that co-ordinates its members' disaster appeals. The DEC entered the CAF rankings in the 2004 report in its own name (with $£ 9.6 \mathrm{~m}$ of voluntary income) but it is excluded from our analysis since it was not present in the Top 500 rankings in earlier years.
} 
we have re-assigned data to the appropriate calendar year, applying the rule that where the charity's reporting year finishes before June 30th the observation is assigned to the previous calendar year. The last year of data in our panel relates to 2004. The assigned year is typically not the year in the title of the CAF report: for example, from Table 1 it may be seen that Oxfam's data for 2004 (year ending in April 2005) was published in Charity Trends 2006.

Repeat observations. Where a very large charity failed to respond to CAF's request for information or where data for a year were missing for some other reason, CAF's practice was to repeat the figures given in the previous year's report. We have identified these observations and deleted the repeated values. In a small number of cases including Oxfam and Save the Children, we have obtained the missing information from the charity accounts.

Missing observations. Where data are missing for a single year, we interpolate linearly using the observations for the previous and subsequent year. Missing data arise for several reasons, including our adjustment for repeat observations, the absence of reports in 1981 and 1995, and the fact that a charity may just drop out of the rankings due to a bad year (or a good year by other charities of a similar size). Very occasionally we 'fill-in' missing observations from earlier years if we know the charity certainly existed but is not present in the dataset e.g. UNICEF in 1978-1980. ${ }^{7}$

Name changes. A considerable number of charities change their names over time; others are recorded in the CAF files under slightly different names in different years. In these cases we collect the annual observations under a single name. ${ }^{8}$

Our aim in making these time-consuming adjustments has been to ensure the highest possible degree of consistency over time. Nevertheless, there remain problems, particularly those due to external changes, such as those resulting from the Charity Commission's Statement of Recommended Practice (SORP) for charity accounting, which affected the treatment of charity shops and of government grants. Prior to 1995, most charities reported the net profit of their shops after deducting the cost of selling goods donated. The switch to reporting the gross value of these goods as a result of the SORP in that year had a dramatic upward effect on voluntary income

\footnotetext{
${ }^{7}$ Missing values have been linearly interpolated. Such filling in has generally been restricted to single missing years. However, in the case of UNICEF the first three years have been filled in using the average growth rate over the period.

${ }^{8}$ Charities occasionally merge, with the most obvious example being the merger in 2001 of Imperial Cancer Research and the Cancer Research Campaign to form Cancer Research UK. We identified a total of 8 mergers in the period as a whole, none of them involving development charities.
} 
for those charities for which this heading is important, e.g. Oxfam, although some charities asked CAF to continue reporting only their net profit for several years afterwards, in order to avoid an impact on their figures which they felt gave a misleading picture of the actual value of voluntary income. We examine the sensitivity of the results later. The SORP defines voluntary income as including grants from all sources, whether private or statutory, and CAF chose to reflect this decision in the definition used in the 2007 edition of Charity Trends. These grants are particularly important for overseas development charities, as we discuss in Section 7, representing nearly 30 per cent of their total income (CAF 2004: 87). The figures for voluntary income for 2007 are therefore not comparable with those for earlier years, which is why we do not use these data.

\section{Summary}

The CAF data are a rich source that allows the construction of a panel data set on donation income for individual charities covering a long run of years (from 1978 to 2004). The data are not fully consistent in all respects but we have invested considerable efforts to improve the degree of comparability and believe that, with these adjustments, the panel provides the basis for studying the evolution of giving over more than a quarter of a century.

\section{The number and rank of overseas development charities}

What do our panel data tell us about the rise of development charities? A total of 69 different overseas development charities appear in Charity Trends at least once between 1978 and 2006. As noted earlier, we define such charities as those with a principal focus on overseas development and relief, where this includes some that serve domestic as well as overseas causes. Since the coverage of the CAF data increased during this time it is useful to look at the number of development charities in the top 200 for the full period, and the number ranked 201-400 (the "next 200") for 1986-2004 - see Figure 2. It should be noted that, when referring to charities' ranks in the data for a given year, we are not referring to the CAF ranks. Instead we have reranked the charities based on the adjustments to the data described in Section 2. That is the rankings now refer to assigned years (not the year of the CAF report in which the data were published) and are based on donations (total voluntary income minus 
legacies). ${ }^{9}$ The correlation between our ranks and the CAF ranks is high (over 0.9) but the procedure adopted here seems more appropriate for our purpose.

Prior to 2000 there was a clear upward trend in the number of overseas development charities in the top 200, which increased from 14 organizations in 1978 to 29 in 2000. This is the first indication of growth in the sector: at the beginning of the period, 1 in 14 of the top 200 charities focused on development; by 2000 it was 1 in 7. The number of development charities ranked $201^{\text {st }}$ to $400^{\text {th }}$ varies between a third and a half of the number ranked $1^{\text {st }}$ to $200^{\text {th }}$. Moreover, the number in this group exhibits a downward trend over the period, suggesting that development charities have a tendency either to become large and successful or to fade away.

Figure 2 near here.

Part of the story of the changing numbers of charities involves the foundation of new charities. Some care is needed here. We cannot say anything about how many overseas development charities were established in a given year in the sector as a whole - all we can examine is the dates of foundation of those charities that end up among the largest 500 fundraisers. With this caveat, we find that the establishment of the development charities covered by the CAF data has been very uneven over time. While a handful of our total of 69 development charities go back to the $19^{\text {th }}$ century, nearly half were established between 1971 and $1993 .^{10}$ The 1980 s saw the establishment of 22 new charities in our data, nearly a third of the total and more than twice as many as in any other decade; 17 of those were founded before 1986 and seven new charities were established in 1985 alone. Those charities founded after 1980 took an average of five years to enter the CAF rankings. Some appeared the very year they were founded (e.g. Band Aid Trust which derived its income from a single large global emergency appeal) while others took as long as fifteen years to work their

\footnotetext{
${ }^{9}$ There is one exception that affects the years 2002-2004. As charities that appeared for the first time in the 2004 Charity Trends report (with data referring to about 2002) or later were dropped from the panel (see footnote 2), this caused an artificial rise in the rank of some of the smaller charities in our panel. To overcome this, for 2002-2004 we used CAF ranks, based on the top 500 in those years, for charities ranked $200^{\text {th }}$ or lower.

10 The historical development of charities for the purpose of overseas relief and development is discussed in Nightingale (1973, Chapter 7). Dates of foundation were obtained by inspecting charity websites and contacting them if necessary. Note that the Charity Commission website records the date of registration of a charity in its current form, which may well be some time after foundation. For example, the date of registration for UNICEF is given as 1998.
} 
way into the data (e.g. Global Care). Since 1993, however, there has been a dramatic fall off in the establishment of new charities: no international development charity established after that year had entered the CAF top 500 as of 2004.

Why did the number of development charities fall towards the end of the period? In part this reflected the change in the criteria for inclusion in Charity Trends noted earlier. From the 2004 edition, "single interest” organizations were for the first time included. This had the effect of bringing in some large non-development charities that were previously excluded and pushing out some existing charities from the rankings, including some in the overseas development sector. As described in section 2, CAF reports for a given year typically cover data from an earlier reporting year, so that the impact of the change in criteria is seen in the data before 2004. As a consequence, the number of development charities included in the lower rankings falls after 2000 (marked by the vertical line in Figure 2). There are only 2 development charities ranked $401^{\text {st }}$ to $500^{\text {th }}$ in 2003 and 2004, whereas previously there had been 4 in the year $2000 .^{11}$

\section{Development charities tend to be large}

Figure 2 demonstrates a tendency for overseas charities to be large. In 2000 there were altogether 44 development charities in Charity Trends, so that if they had been proportionately represented, we would have expected to find only 18 in the top 200, whereas there were in fact half as many again (29). From 1978 to 2004, the average rank of development charities in the top 200 of all charities is $69^{\text {th }}$, or $31 \frac{1 / 2}{2}$ places above the expected rank. From 1991 onwards, for those in the top 500, the average rank of development charities was $161^{\text {st }}$. These are the highest average rankings for any of nine broad categories of charity in the CAF data. ${ }^{12}$ Development charities are more likely to appear at the top of the size rankings.

In Figure 3, the first bar shows the number of times that development charities were ranked in the first five places among the top 500 over the 14 years from 1991 to

\footnotetext{
${ }^{11}$ Another recent change was CAF's switch to data supplied by CaritasData, although it is not obvious that this should have resulted in any marked changes.

${ }^{12}$ Note that we have amalgamated a number of the categories defined in the CAF data.

The other eight categories, with CAF component categories in parentheses, are Medical (AIDS, Cancer, Chest \& Heart, Terminal Care, Mental Health, Other Medical, Hospitals), Disabled (Disability, Blind, Deaf), Children (Children, Youth), Religious (Religious General, Religious Missionary), Elderly \& Benevolent Funds (Elderly, Services/Ex-Services, Benevolent Fund), Animal, Environment and Heritage, and Other (Other General \& Social Welfare, Recreation, Israeli, Education, Arts).
} 
2004. Each observation corresponds to 1 charity/year. The second bar shows the number of times a place in ranks six to 10 was achieved, and so on. The reference line shows the number of charities we would expect in each case were the distribution uniform for all charities for all causes. In fact, the development charities appear above the line (more than expected) for the highest rankings: they tend to be among the largest charities.

Figure 3 near here.

\section{Summary}

Over the period since 1978, development charities came to be increasingly represented in the top 200. At the beginning of the period, 1 in 14 of the top 200 charities focused on development; by 2000 it was 1 in 7 . Over the period since 1986, the number in the next 200 exhibits a downward trend, suggesting that development charities have a tendency either to become large and successful or to fade away. Development charities do indeed tend to be large, having the highest average rankings for any of nine broad categories of charity in the CAF data.

\section{The growth in the voluntary income of development charities}

What is the income of the development charities and how has it grown over time? Here we examine giving in real terms, all figures being expressed in 2007 prices using the UK Retail Price Index. We leave on one side for the present legacies and focus on the sum of all other forms of voluntary income, which we refer to as 'donations', although, as noted in Section 2, these include items other than donations by individuals.

The $25^{\text {th }}$ Anniversary edition of Charity Trends reported that "cancer and international causes have consistently been the most popular causes to support over the last 25 years; giving to international causes has grown even more over that period than to cancer charities" (CAF 2004, page 13). Figure 4 shows the growth of donations made to development charities in the top 200 and the next 200 (from 1986), measured on a log scale so that a straight line corresponds to a steady proportionate rate of growth. From 1978 to 2004, the total contributed to those charities in the top 200 increased in real terms from $£ 106$ million to $£ 719$ million. The average annual 
growth rate across the period was 7.5 per cent - see the first entry in the last column of Table 3. ${ }^{13}$ This rate of growth was substantially larger than the average annual increase in total household after-tax income of about $2 \frac{1}{2} 2$ per cent. The growth rate for development charities exceeded that for non-development charities in the top 200, which was 5.7 per cent. Giving to development charities ranked between 201st and 400th also grew substantially: the contributions made to this group of smaller charities rose from $£ 5.2$ million in 1986 to $£ 27.4$ million in 2004. Although the total they receive is clearly dwarfed by the donations going to those in the top 200, the smaller charities grew faster: a total increase of 423 per cent between 1986 and 2004, compared with growth of 124 per cent over the same period for the larger development charities. Over the period 2001-4, the smaller charities grew roughly the same amount as the larger charities (21 per cent vs. 25 per cent) though much of this slowdown can be attributed to the fall in their number during these years.

Figure 4 near here.

Table 3 near here.

A focus on donations to all charities in the top 200 (or 400) does not tell us anything about giving to any individual charity, as the number of charities included in any given year changes. As may be seen from Figure 2, these changes may be abrupt: from 1983 to 1985 the number of development charities in the top 200 rose from 19 to 27. As an alternative, we therefore examine the amounts received by the largest 14 charities each year in terms of donations (as defined at the start of the section), 14 being the minimum number in the top 200 in any year given our adjustments to the data (e.g. filling in missing values). This allows us to examine annual changes over the period for a consistent number of charities in each year, although of course their identities will not necessarily be constant. Figure 5 shows both the total donations going to the top 14 and the total going to all development charities in the top 200, as in Figure 4. (The figures this time are shown in levels rather than logs.) The difference provides an indication of the extent to which the growth in Figure 4 was due to the increased number of charities. By 2004, the 14 largest charities were raising £667 million in donations, with an annual average growth rate over the whole period of 7.3

\footnotetext{
${ }^{13}$ The growth rate, g, over a period of $\mathrm{T}$ years is calculated using the ratio, $\mathrm{R}$, of the end year to the beginning year and the formula $\mathrm{R}=(1+\mathrm{g})^{\mathrm{T}}$.
} 
per cent (second entry in final column of Table 3), which is only slightly less than the increase for all overseas charities in the top 200.

Figure 5 near here.

\section{Different phases of growth}

There was therefore substantial real growth in giving to development charities between 1978 and 2004. But the growth was far from steady, as is evident from Figure 5, where the early 1980s emerges as a very significant time. As noted earlier, from 1983 to 1985 the number of development charities in the top 200 rose by 8 and total contributions to those charities increased over 130 per cent. This surge in numbers and amounts has however to be seen in the context of the period as a whole.

In Figure 5, we have identified by vertical lines four distinct periods: 1978-83 (before the "surge”), 1983-85 (the “surge”), 1985-97 (“marking time”), and 19972004 ("renewed growth”). Table 3 gives the average annual growth rates for each of these periods. These differ markedly. A major change took place in the mid-1980s and the cause is evident. The Ethiopian famine of 1984-85 brought a huge public response. This was in part stimulated by the work of Bob Geldof, who organised the Band Aid Christmas single ('Do they know it's Christmas?') in 1984, with the proceeds going to the Band Aid Trust, and the Live Aid concerts in 1985. Oxfam had a record year in 1984, with its $£ 109$ million of donations (in 2007 prices) nearly double the level of the year before. In 1985 the Band Aid Trust was the charity with the highest donations in the UK, bringing in $£ 122$ million (again in 2007 prices). Oxfam also had a significantly better than average year in 1985, though its contributions were 25 per cent down from the 1984 total.

One question that arises is whether these apparent changes reflect doublecounting. Did the Band Aid Trust give its money to other development charities, causing double-counting? In fact, our inspection of the accounts of Band Aid suggests that the majority of its income was spent directly on the charity's own relief efforts in the early years. The charity’s accounts for 1985 show only £5.5m of expenditure (in 1985 prices) in grants to other (unnamed) relief agencies; rising to $£ 14.6$ million in the 1988. While these are not trivial amounts, when we take account of the fact that part of these unnamed grants were made directly to overseas 
organisations, it seems reasonable to conclude that double counting is relatively modest. $^{14}$

Following the years of the famine, overseas giving fell sharply, by about a third in 1986. But donations in this year were still double the average for 1980-82. The apparent impact of the crisis was to produce a large persistent upward shift in the level of giving to development charities. The rest of the period 1985-97 shown in the graph was one where growth was positive, but modest - just under $3 \frac{1}{2}$ percent for the top 14 development charities. The 1997 total for the top 14 was well below that which would have been attained if donations had grown steadily at a rate of 7.3 per cent since 1978.

From 1997, overseas development charities saw again a sharp increase in voluntary contributions. Growth to 2004 averaged 9.1 per cent per year for the top 14 and 7.0 per cent for all development charities in the top 200. This change coincided with the arrival of the Labour government and its pledge to increase ODA, following years of stagnation - see the Introduction. It is clearly possible that the level of public awareness and concern was increased as a result of the attention paid to issues of development, particularly with regard to Africa, by the Prime Minister and the Chancellor of the Exchequer. Increased ODA may have had a positive effect on charitable giving.

On the other hand, the increase in overseas giving in the later 1990s may have been quite independent of government. It may have been a manifestation of increased globalisation. As one way of placing in context the growth of charitable support for development, we show in Figure 6 the real spending by UK residents on visits abroad (data from the International Passenger Survey). There is no surge in the latter, but the two series otherwise move closely together. Growth in the period from the mid-1980s to the mid-1990s is slower, with acceleration after 1996. From 1978 to 2004 as a whole, the growth rate is very similar. At the beginning of the period, as at the end, on average the UK population spent in a week on visits abroad what they gave in a year for overseas development and relief (the left hand scale is a $50^{\text {th }}$ of that on the right). Increased expenditure might have been due to the growth of contacts within the European Union. However, the International Passenger Survey data also show that

\footnotetext{
${ }^{14}$ The 1985 accounts note that grants to other agencies 'comprise amounts collected as donations by certain overseas agencies as a result of the Live Aid concert. The sums collected were retained by those agencies and used to fund their famine relief efforts in Ethiopia and the surrounding area' (note 8).
} 
spending on visits to "other countries" grew faster (average annual growth rate of 12.2 per cent between 1982 and 2006) than travel to Europe (average growth 9.2 per cent) or North America (average growth 9.5 per cent) (Travel Trends 2006, Table 1.06). The similarity in trend between spending on visits and donations for overseas development may reflect the fact that both are influenced by similar developments in our society - such as a greater sense of security - or there may be a direct link. Travel may mean that people identify more readily with the circumstances of those living in poor countries. First-hand experience of conditions in Asia or Africa may mean that people are more ready to respond to disasters.

Figure 6 near here.

\section{Legacies}

We now turn to legacies. We have already noted that bequests to development charities are a much less important form of voluntary income than for other charitable causes. Nevertheless, development charities have experienced substantial growth in this form of income as well. Legacies received by all charities in the top 200 increased from $£ 15$ million in 1978 to $£ 78$ million in 2004. (We again express all figures in 2007 prices using the Retail Price Index.) This represents (see third row of final column of Table 3) an average annual growth rate of 6.5 per cent (other donations grew at 7.5 per cent). ${ }^{15}$ Figure 7 plots the total over the period together with the total going to the four largest development charities in any year (ranked in terms of legacy income). The series for all development charities shows a spike in 2000, which mirrors that for donations in Figure 5, but in contrast to the pattern for donations there is no quick recovery.

The growth rates of legacies to all development charities in the top 200 are shown for sub-periods in Table 3. Bequests have not gone through the same distinct periods as inter-vivos contributions, though the increased growth rate in the mid1980s does reflect the similar large increases seen in donations at that time. In other research with microdata on estates in which charitable bequests have been left (the data cover 2007-8), we find that wills are quite often made or altered within just one

\footnotetext{
${ }^{15}$ It should be noted that, for some charities (in the sector as a whole), legacies are known to be included in the figure for donations rather than being separately identified, especially in earlier Charity Trends reports.
} 
or two years of death. It is hence possible that the sharp increase in the growth rate of legacy income in 1983-85 was brought about by a common driver, famine in Africa. The 5 to 6 per cent annual growth in legacies over 1985-2004 may also be part of this story, although a thorough investigation would need to consider other factors, including house prices and the state of the stock market.

Figure 7 near here.

\section{Summary}

Donations apart from legacies for development charities in the top 200 grew at a rate of $7 \frac{1}{2}$ per cent per annum over the period since 1978, and the same applies to the income of the largest 14 development charities (at any point in time). Legacies grew at a slightly slower rate (61/2 per cent), but this is still more than double the growth rate of household income. Growth in total donations to development charities was far from steady over time. We have identified four distinct periods: 1978-83 (before the "surge”), 1983-85 (the “surge” associated with African famines), 1985-97 (“marking time”), and 1997-2004 (“renewed growth”).

\section{The growth of existing charities, new entrants and the degree of concentration}

Behind the aggregate picture described in Section 4 lie the movements of individual charities. We have studied the top 14 development charities in each year, but the top 14 are not the same from year to year: in fact 35 different charities appear at least once in this group. In Figure 8, we show the donations (excluding legacies) given individually to eight of the largest development charities. In Charity Trends 2004, they were 3,11,13, 19, 22, 26, 46 and 47 in the overall rankings of charities. The amounts shown are measured in real terms on a linear scale, and relate to donations over the full period for seven and from 1979 in the case of CAFOD. (It should be noted that the vertical scales are different in the two parts of Figure 8.)

Figure 8 near here.

Giving to individual charities is highly volatile and annual changes of several million pounds are not unusual. We have already referred to Oxfam's sharp growth at 
the time of the Ethiopian famine. In the reported data, Oxfam had another apparent huge surge in donations in 1994. This 1994 surge is not reflected in the data for any of the other charities and appears to be an artefact of a change in reporting practice discussed in Section 2: the switch following the 1995 SORP from reporting net profit from donated shop goods to the gross value of the goods. This has been confirmed by examining Oxfam's annual reports for the period. They did switch from reporting net shop income ( $£ 14$ million in 1994) to reporting gross shop income ( $£ 63$ million in 1994). (These figures represent $£ 20$ million and $£ 87$ million respectively in 2007 prices.)

Save the Children also had a sharp rise in donations during the Ethiopian crisis, and then another notable increase in 1991. This appears to be a genuine spike in donations, driven in part (as far as we can tell from the charity's annual reports) by gifts in kind. As a result, Save the Children overtook Oxfam but donations then declined until 1995 before growth set back in. There are spikes of varying size (and timing) in the mid-1980s for Christian Aid, Tearfund, CAFOD, and UNICEF, but none for the Red Cross nor ActionAid, showing that not all charities see a rise in donations rise during a major emergency (some may not be involved in disaster relief). Oxfam, Tearfund, and CAFOD show very sharp rises in income in 2004 (CAFOD's income doubled) the reasons for which are unclear. One possibility is that the figures reflect donations following the Asian Tsunami in December 2004 (in each case the figures relate to the tax year, 2004-5).

As is clear by eye, the overall growth rates differed very considerably. Over the whole period from 1978 to 2004, UNICEF grew at an annual average rate of 14.7 per cent. (This average growth rate is calculated from the end points; it is not the same as the average of annual growth rates.) CAFOD grew at an annual average rate of 9.5 per cent, ActionAid at 9.2 per cent, Sightsavers are 8.2 per cent, Oxfam at 7.5 per cent, Red Cross at 7.0 per cent, the Tearfund at 6.9 per cent, Save the Children at 5.4 per cent, and Christian Aid at 4.9 per cent. There were consequent changes in the relative sizes of different bodies. In 1978, ActionAid was a third of the size of Christian Aid; by 2004 they both received $£ 62$ million. If Save the Children had grown at the same overall rate as Oxfam, it would have had an extra $£ 47$ million in 2004.

Table 4 provides more information on the individual growth for the 14 charities that were in the top 200 in 1978. These comprise 7 of the 8 shown in Figure 
8 (the data for CAFOD only start in 1979). Of the other 7, four dropped out of the CAF rankings. The four reflect changing times. The Co-Workers of Mother Theresa had left the rankings even before her death in 1997. War on Want (whose name had been devised by Harold Wilson) ran into difficulties at the end of the 1980s, but was re-launched in 1991. The remaining ten charities were still present in the top 500 in 2004. The charities are ordered on their 1978 donations and for 7 out of the 10 survivors the ranking in 2004 is similar, not differing by more than 1 position (the rank correlation is 0.92). The differences in growth rates were not in general large enough to change the rankings, but they were large enough to mean that the simple correlation of initial and final donations for the 10 survivors was only 0.60 .

Table 4 near here.

New and old development charities

How much of the growth of donations has been due to charities that already existed at the end of the 1970s and how much due to new charities established subsequently? Figure 9 shows the percentage of donations (defined again as voluntary income less legacies) to all development charities in the top 200 that was received by charities that were founded after 1978. The large spike in 1985 reflects the birth and instant success of the Band Aid Trust. Leaving the mid-1980s aside, the figure is typically around 10 per cent, underlining the importance of long-established charities in the sector's total fundraising. The falling back of the series after the mid-1980s surge shows that the upward shift in giving to development that followed the Ethiopian crisis was largely due to the success of 'old' charities. The new charities may have helped raise awareness and lever new funds into the sector, but they do not appear to have been the main long-term beneficiaries of the change in public sentiment. Indeed, Band Aid itself was not intended to be long-lived.

Figure 9 near here.

Another way to measure the success of new charities is to consider their growth rates once they enter the CAF rankings compared to those of existing charities. This calculation excludes consideration of growth prior to entry into the data and nor can we measure growth in any year in which a charity falls out of the 
rankings. In practice, we estimate annual growth by pooling all the observations over time for charities in the two groups, pre- and post-1978 foundation, and then for each group we regress the natural logarithm of donations for each charity on a time trend. The estimated annual rates over the full period are 7.0 per cent for both groups. Note that these rates should not be compared directly with the rates in Table $3 .^{16}$

Regressions for sub-periods indicate that the new charities grew slightly more rapidly over 1983-5 and 1986-96 but there is very little in it.

\section{The degree of concentration}

How far are donations dominated by the largest charities? This is the same question as that asked by industrial economists: if a small number of firms produce most of the industry's output then we say that industry is highly concentrated. A commonly used measure of concentration is the n-firm concentration ratio which consists of the market share, as a percentage, of the $n$ largest firms in the industry. The concept of market concentration and the n-firm ratio can be applied to charities, as we do below (considering the share received by the largest 4 charities). We can examine whether or not there been increasing concentration. At the same time, the interpretation of the answer is not necessarily the same. In the industrial context, concentration is generally interpreted as indicative of an oligopolistic market, where there is a risk of collusion among the leading firms or other behaviour designed to restrict entry into the industry. In contrast, in the case of development charities, explicit collaboration to raise donations from the general public may be welcomed. This does indeed take place via the Disasters Emergency Committee (DEC). ${ }^{17}$ The DEC 'unites the UK's leading independent humanitarian agencies in their efforts to raise income through media appeals'. The current arrangement is that, after a major international disaster, the public is encouraged to donate to the DEC which then divides the income between its members according to a pre-agreed formula.

\footnotetext{
${ }^{16}$ They represent average growth rates for individual charities across periods when they are observed in the data, which is a different concept to the growth rates for a (changing) group of charities in which the group is taken as the unit of analysis.

${ }^{17}$ http://www.dec.org.uk/item/197/248/0/0. The DEC was formed in 1963. It is currently composed of 13 charities, including many of the largest fundraisers: members are ActionAid, British Red Cross, CAFOD, Care International, Christian Aid, Concern, Help the Aged, Islamic Relief, Merlin, Oxfam, Save the Children, Tearfund and World Vision. DEC raised £372 million in its Tsunami appeal, £59 million for the victims of the 2004 Asian earthquake and $£ 32$ million for food aid to Niger.
} 
Figure 10 shows concentration ratios for both donations (total voluntary income less legacies) and legacies. In both cases we limit attention to development charities in the top 200 as the base for the calculation; if we were to include all development charities then the degree of concentration would be a little lower. This has to be taken into account when considering the very high level of concentration recorded; as may be seen from Figure 10, initially around 70 per cent of donations were received by the largest 4 charities. Interestingly, concentration of donations has declined over time, the four-charity ratio falling from around 70 per cent to around 50 per cent. Approximately half of this 50 per cent accrues to Oxfam. These results are consistent with the notion that while donors have increased their total contributions to development charities, they have also increased the number of charities to which they give. Nevertheless, donations to the development sector remain highly concentrated with levels that are at least as great as in the UK pharmaceutical, telecommunication and oil and gas industries, where the top 5 businesses produce around 55 per cent of total output (Mahajan 2006, Table 6).

Figure 10 near here.

Although legacies, like donations, have increased substantially over time, the degree of concentration has remained fairly stable and exhibits no downward trend. Moreover, the concentration of legacy income is substantially higher than that of donations: the largest four received about three-quarters of all legacies received by charities in the top 200. This suggests that, while donors may be willing to spread their donations around while alive, bequests tend to be reserved for a smaller group of development charities.

\section{Summary}

The advantage of the panel data set constructed here is that it allows us to follow the histories of individual development charities. The sector is highly concentrated, with half of total donations accruing to the four largest charities, but the experiences differ considerably across the charities. The average annual growth rates of the "big four" (Oxfam, Save the Children, the Red Cross, and Christian Aid) range from 4.9 per cent to 7.5 per cent. An important feature has been the arrival of new charities, but there is no strong evidence that they have grown faster. The new 
charities may have helped raise awareness and lever new funds into the sector, but they do not appear to have been the main long-term beneficiaries of the change in public sentiment.

\section{How has overseas development fared compared to other charitable causes?}

It is clear that the development sector has undergone impressive growth and some significant structural changes over the period. The question remains whether or not this was unique to the sector or whether a broader increase in all giving took place. Figure 11 plots donations (in constant prices and on a log scale) made to all development charities and donations to charities serving other causes. Donations are defined again as all 'voluntary income' apart from legacies and the analysis is once more restricted to the top 200. (The series for development charities is therefore the same as that top line in Figure 4.)

It is immediately obvious that charitable giving as a whole has experienced a great expansion - development is far from being the only sector to experience high levels of growth over the period. The mid-1980s saw much higher growth rates for development charities (as the series are in logs the slopes at any point show the growth rates) but following the Ethiopian famine the series appear to diverge, implying higher growth for the other non-development causes. The market share of all donations of the development charities in the top 200 has not changed monotonically over the period. Giving to the sector rose from about a fifth of all donations in 1978 to over two-fifths in 1985 with the advent of Band Aid, but the share then fell back over the years. In 2004, a quarter of all donations went to the development sector.

Figure 11 near here.

Table 5 considers the changes in more detail, showing the average growth rate for all other charities over the sub-periods used earlier in Table 3 and also the growth rates for each category of charity separately. Comparison of the last two rows in the table (which correspond to the lines in Figure 11) confirms that when taking the other charities together as a group, their donations grew faster during 1985-97 but that development charities grew faster in all other sub-periods. Over the period as a whole, giving for development rose more quickly: at an average annual rate of 7.5 per cent, compared with 5.7 per cent. Development therefore differs not just in the surge of 
1983-5 but also in the long-term growth rate. If we iron out the dependence of these calculations on the start and end year values by comparing average donations in 197880 with those in 2002-4, the difference in growth rates is still nearly 1 percentage point. A difference of 1 percentage point per annum makes a great deal of over the years: if giving for development had grown since 1978 at an average rate of 6.5 per cent, rather than the 7.5 per cent achieved, then the total in 2004 would have been about $£ 150$ million smaller. This is the equivalent to the loss of all of the donations to Save the Children, ActionAid and UNICEF in that year.

Looking at individual causes, we see that over the whole period 1978-2004 development grew faster than all others apart from "medical" and "animals". Over the most recent period, 1997-2004, these two groups were the only ones to match or exceed the growth rate of development. The two "rival” causes are however very different in size. The "medical" cause received (average for 1997-2004) an amount not dissimilar to that for development, but, despite popular perceptions, the average amount given for animals was only about $1 / 6^{\text {th }}$ of that given for development. (Note that these figures do not include legacies, which are much greater for animals than for development.) Put differently, the average annual amount given for animals in 19972004 was $£ 84$ million more than in 1978-1982, whereas the amount given for development was $£ 417$ million more (both figures in 2007 prices).

Table 5 near here.

\section{Summary}

Giving for development has grown faster than giving for all other causes taken together. In part this reflects the "surge" in 1983-5 but growth has been faster in all sub-periods apart from 1985-1997. Only "medical” and “animals” have grown faster overall, and the latter is much smaller in scale.

\section{Government giving for development through UK charities}

In contrast to private giving, UK government giving to overseas development assistance (ODA) stagnated over much of the period with which we are concerned in this paper. But as we noted in the Introduction, ODA includes grants made by the government to UK development charities. A stagnating total for ODA is consistent 
with an increase in these grants if there has been a shift from other forms of government giving for development (government-to-government or via multinational organisations such as the World Bank and the UN) towards making grants to UK charities. Indeed, this has happened, as has been documented by Mosley and Eeckhout: "since 1980, overseas aid has transformed itself. Although seeking to perform the same purpose ... it now uses different instruments to achieve that purpose” (2000, page 131). As project aid for governments was cut back, aid was switched towards the private sector and NGOs. Mosley and Eeckhout go on to say that "when poverty focus came back in to fashion in the 1990s ... non-state agencies, and not developing-country governments, took much of the responsibility for implementing it” (2000, page 136). If government grants to development charities have expanded significantly and if this has helped charities to attract more private donations, then a simple story of stagnating government generosity and rising private generosity is misleading. And if grant income has grown but grants 'crowd out' private giving by making people less willing to give (since they are already giving more through their taxes), as assumed in simple economic models of charitable donations, the growth in the voluntary income of charities would be even more remarkable. $^{18}$

How large are government grants to charities? Here we have an alternative source, which provides an independent check on the validity of the CAF data that we have been using in this paper. From the accounts of the Department for International Development (DfID) (and its predecessor the Overseas Development Administration) a total can be constructed from 1982 (data before 1982 are not available). These DfID data do not include grants to charities from other public bodies, such as the EU; and the CAF figures do not cover all charities. So we should not expect the exact coincidence. However, it may be seen from Figure 12 that the totals (which are shown in constant prices) move very closely together. ${ }^{19}$ This is reassuring in terms of the quality of the CAF data. Both series show that grants to charities have increased from around $£ 25$ million at the beginning of the 1980 s to a figure 10 times that

\footnotetext{
${ }^{18}$ In other work with Wiji Arulampalam, University of Warwick, we estimate econometric models that aim to shed light on the strength of the relationships in the panel of data.

${ }^{19}$ The CAF data are not shown for 1997 to 2000 as there are missing values for the Red Cross, which was a major recipient (£84 million in 2001). If we were to impute figures for the Red Cross for this period, based on the pattern of year-to-year change in the DfID data, the CAF series would show no fall.
} 
amount. ${ }^{20}$ This increase is well above the 6-fold rise in donations to development charities over the same period. The total of $£ 250$ million in 2004 may be compared with the total voluntary income of development charities of about $£ 1$ billion. There has not however been a steady increase in government grants. The total had reached $£ 250$ million by the 1990s. Between 1986 and 1994, the amount increased by a factor of 5 , but now appears to have levelled off.

Figure 12 near here.

The magnitude of government grants, and their time path of growth, may well have influenced the level of private giving. From the information for individual charities, it is possible to examine whether those with larger increases in government grants also saw a larger increase in donations. In order to test this fully, however, we need to consider the full range of factors that may have influenced private donations for development, both those affecting the sector as a whole and those affecting individual charities. We have also to recognise that the allocation of government grants to charities may be influenced by some of the same factors that influence private donors in deciding which charities to support (the endogeneity of government grants is treated using CAF data for 1983 to 1990 by Khanna and Sandler, 2000). The receipt of government grants may also affect the fund-raising activities of the charities. These issues can all be explored using the long panel we have assembled.

\section{Summary}

There is independent information on the total of government grants to development charities, and this provides a reassuring cross-check on the accuracy of the information in the CAF files. These grants have increased from around $£ 25$ million in the early 1980s to a figure 10 times that amount in 1994, and have since levelled off up to 2004.

\section{Conclusions}

The principal conclusions of the paper may be summarised as follows:

\footnotetext{
${ }^{20}$ From 1994 the DfID grant data identify the main recipient charities (about 50 per year). Pooling the CAF and DfID observations for these charities for 1994-2004, we find a correlation coefficient for the individual grant amounts (in constant prices) in these two sources of 0.92 . (This calculation is for charities where both sources record positive amounts; we exclude the Red Cross for 1997-2000).
} 
- The CAF data are a rich source that allows the construction of a panel data set on donation income for individual charities covering a long run of years (from 1978). The data are not fully consistent in all respects but we have invested considerable efforts to improve the degree of comparability and believe that, with these adjustments, the panel provides the basis for studying the evolution of giving over the quarter century since 1978 . When compared with the independent evidence with regard to government grants, the CAF data in general perform well.

- Over the period since 1978, development charities came to be increasingly represented in the top 200. At the beginning of the period, 1 in 14 of the top 200 charities focused on development; by 2000 it was 1 in 7 . Over the period since 1986, the number in the next 200 exhibits a downward trend over the period, suggesting that development charities have a tendency either to become large and successful or to fade away. Development charities tend to be large, having the highest average rankings for any of nine broad categories of charity in the CAF data.

- Donations apart from legacies for development charities in the top 200 grew at a rate of $71 / 2$ per cent per annum over the period since 1978 , and there was similar growth in the income of the largest 14 development charities (at any point in time). This compares with annual average growth in total household income of about $2 \frac{1}{2}$ per cent. However, the growth rates of donations in the development sector differed considerably across individual charities: the average annual growth rates of the "big four” range from 4.9 per cent to 7.5 per cent.

- Legacies grew at the slower rate of $61 / 2$ per cent, but this is still more than double the growth rate of national income.

- Growth in donations was far from steady over time. We have identified four distinct periods: 1978-83 (before the “surge”), 1983-85 (the "surge” associated with African famines), 1985-97 (“marking time”), and 1997-2004 (“renewed growth").

- The panel data set constructed here allows us to follow the histories of individual development charities. The sector is highly concentrated, with half of total donations accruing to the four largest charities. An important feature 
has been the arrival of new charities, but there is no strong evidence that they have grown faster. The new charities may have helped raise awareness and lever new funds into the sector, but they do not appear to have been the main long-term beneficiaries of the change in public sentiment.

- Giving for development has grown faster than giving for all other causes taken together. In part this reflects the "surge" in 1983-5 but growth has been faster in all sub-periods apart from 1985-1997. Only “medical” and “animals” have grown faster overall (leaving aside legacies), and the latter cause is much smaller in scale.

- Government grants to development charities have increased from around £25 million in the early 1980s to a figure 10 times that amount in 1994, and have since levelled off up to 2004. They represent a significant amount in relation to the sector's total voluntary income. 


\section{$\underline{\text { References }}$}

CAF (2004) Charity Trends 2004: $25^{\text {th }}$ Anniversary Edition, CAF and CaritasData.

CaritasData (2008) Top 3000 Charities 2008/09, CaritasData, London.

Khanna J, Posnett J and Sandler T (1995) "Charity donations in the UK: New evidence based on panel data”, Journal of Public Economics 56: 257-72

Khanna J and Sandler T (2000) "Partners in giving: the crowding-in effects of UK government grants”, European Economic Review 44: 1543-56

Mahajan S (2006) "Concentration ratios for businesses by industry in 2004” Economic Trends, 635: 25-47.

Mosley P and Eeckhout M J (2000) "From project aid to programme assistance”, in Tarp F, editor, Foreign Aid and Development, Routledge, London.

NCVO (2007) The UK Voluntary Sector Almanac: The State of the Sector, NCVO.

Nightingale, B (1973), Charities, Allen Lane, London.

ONS, 2000, “A report on the 1999 International Passenger Survey”, Travel Trends, The Stationery Office, London.

ONS, 2008, "Data and commentary from the International Passenger Survey", Travel Trends 2006, The Stationery Office, London.

Pharoah, C (2008) Charity Market Monitor 2008, volume 1: Fundraisers, CaritasData, London.

Pharoah, C, forthcoming, "Constructing and publishing data on the UK's largest fundraising charities 1977-2007”, Working Papers, ESRC Research Centre for Charitable Giving and Philanthropy, Cass Business School, www.cass.city.ac.uk/philanthropy.

Robinson M, 1993, "International Aid Charities in Britain” in S Saxon-Harrold and J Kendall (eds.) Researching the Voluntary Sector, CAF. 


\section{Appendix. Cleaning and assembly of the data}

We were supplied by CAF with 24 Excel spreadsheets, each file referring to the data for one year of Charity Trends 1982-2006. There was no report in 1995. We subsequently entered data from into Excel spreadsheets from the 1978-9 and 1979-80 reports. We did not have access to the 1981 report. For each charity variables were included on components of voluntary income, other income, expenditure, government grants, and assets.

To analyse trends in the data over time we needed to merge the separate files into a single file, which will be called the 'merged file' in what follows. Each observation in the merged file had to represent one charity in one year. As a result of our cleaning of the data described below, our final data set contained 762 charities.

The biggest challenge in preparing the merged file was to clean the charity names. Charity names serve as observation identifiers in our data set since the CAF files contained no unique identifying number for each charity that was the same from year to year. In order for us to follow a charity over time, its name must be exactly the same from one year to the next. As a consequence, it was necessary to produce uniform identifiers for each charity, i.e. to homogenize the charities' names over time. It was quite common that a charity's name would vary from year to year in the raw data files, for one or more of the reasons described below. Without harmonisation of names, our analysis would treat each occurrence as a separate charity.

Different ways of writing and spelling charity names across years. Data were collected by CAF over more than two decades and in general the data for each year were analysed separately. As a result, slightly different names were often used in different Excel files. In particular, names were often abbreviated differently. For example, the charity National Council for Voluntary Organisations was recorded sometimes as "NCVO”, sometimes “N C V O”, and sometimes as “ncvo”.

Name changes. Charity names changed over time, i.e. there were genuine name changes. For example, the "National Society for Cancer Relief” became "Cancer Relief MacMillan” in 1987 and since 1996 the charity’s name has been "MacMillan Cancer Relief”.

Different main and working names. Charities often have different names: main names and working names. For example, the charity with the main name "The National Autistic Society" uses two working names under which it operates, "Autism UK” and "Action for Autism". The name used in the CAF file for any charity can change over time between main and working names. In our cleaning we chose to harmonise on the main name. checking.

Cleaning was done first with computer programs and second through manual

\section{Computerised cleaning of names}

Computerised cleaning was carried out in the Stata package. As a first step, we identified systematic differences in spellings, use of abbreviations, punctuation, and 
capital letters in the merged file, and then harmonised names by imposing a systematic practice in these areas. For example, if names contained punctuation, such as a hyphen or comma, the punctuation mark was deleted. Abbreviations (e.g. 'GB' for Great Britain or 'ASSN' for Association) were changed into the full name.

In order to track charities that had been attributed different names over the years or that had changed names we used an additional file supplied by the Charity Commission (CC). This file contained information on 5,244 charities for England and Wales with a total income (not just voluntary income) of $£ 1$ million or more in 2006 and provided each charity's main name, its current working names, and any old names previously used (old names refer back to the mid 1980s). A quarter of all charities in the file had changed their name in the past, and about a half used at least one working name in addition to their main name. Using this file, we were able to check whether any charity name in the merged file referred to either an 'old name' or a 'working name' in the CC file.

A new variable named clean name was created that became the identifier for the cleaned data set. This variable was set to the CAF charity name if 'no fit' was achieved between the merged file and the CC file, where 'no fit' was defined as the situation where less than 4 words of the charity name was equal in the two files. If a 'fit' was achieved, defined as 4 or more words the same, clean name was set to the CC file main name. The decision to use a match of 4 words (instead of 3 or 5, 6 and so on words) represented a balance between wrongly attributing different charities to the same charity name (less than 4 words) and not attributing the same charities with different names to one charity name (4 words or more).

For a small number of charities (especially those with very long names used also for other charities), this procedure could result in incorrect changes and manual checking was needed to follow up. Note also that 'old names' in the CC file went backwards only to the mid 1980s, and hence name changes that took place at an earlier date could not be cleaned via our program.

\section{Manual cleaning of names}

When the limits of program cleaning were reached we began a process of manually checking each charity's name. The manual cleaning was largely carried out with the use of Excel. An Excel file was created called "Master List.xls" that documents the process and contains the following variables:

- name_w4: This is the name generated as a result of the program cleaning and the starting point for the manual cleaning.

- Years Available Before Cleaning: This is the years available for the program cleaned name (e.g. 1978-1984)

- Note in .do file: This is the "story" of the cleaning for each charity. It is the note that is included in the Stata .do file written to implement the manual checking after it had taken place. Typically the entry for each charity includes identified alternative names and name changes, any potential alternatives, identified reasons for missing years of data, and the results of any correspondence with the charity concerned. 
- Years Available After Cleaning: This gives the years available after the names have been homogenized.

- Total Years Available: This is the total number of years available after the name has been manually cleaned (e.g. 12).

This file is a record of the entire manual cleaning process for each charity and is available from the authors upon request. The manual cleaning process was carried out in as systematic a way as possible. The procedure followed was as follows:

1) A charity identified in the rankings in either 1985 or 2000 using the variable name_w4 was searched for in the panel. Once found, the years readily available for that charity under that name was noted. This is the Years Available Before Cleaning variable.

2) Each word in the charity name was then searched for independently to try and catch mis-spellings and typos remaining after the program cleaning.

3) The CC file was consulted to identify potential alternative names. Each word in any alternatives identified in the CC file was then searched for independently.

4) If the charity was missing for a single year, the ranking (in terms of total voluntary income) in close years was found and then the missing year was searched for around that ranking. But if a charity first appears at a low rank only in the years when Charity Trends was expanded to the top 300 (1984), 400 (1985) or 500 (1991), earlier years were not searched manually. If, however, the charity was missing for, say, 1989 after being ranked in the top 350, it would be searched for manually in earlier years. The manual search involved scrolling up and down the spreadsheet, looking for possible alternatives.

5) If the manual search did not result in suspect missing years being identified, the charity was searched for on the internet to try and verify the year of foundation as well as any milestones that might explain the sudden appearance of a charity in the rankings. For example, YHA did not start fund-raising until the 1990s, so its first appearance in 1991 is not so curious. This was done to identify alternative names, and to find out if there was a reason to keep looking for a particular charity in a particular year.

6) If the charity's own website did not give a date of foundation, the date of registration was obtained from the Charity Commission website. As noted in the main text of the paper, the latter may not be very informative as the dates of registration for some charities are long after the dates of foundation.

7) If questions remained about missing years, the charities were contacted via email to enquire about name changes, mergers, name variations and acronyms.

8) To try to check for our own errors in the manual cleaning process, two methods of verification were used.

a. Initially those charities that appeared in the Top 300 in 1985 and Top 500 in 2000 were 'cleaned'. Then a list of the remaining charities, those that had not been cleaned, was compiled. The cleaning process outlined above was then applied to these charities. This iterative process allowed us to catch charity names that should have been homogenized to one of those in the top 300/500 but was missed in the first iteration.

b. Once each charity had been looked at, a list of all the charities present in the Stata file with the homogenized names was stacked on the list of 
charities complied in the Master List.xls Excel file. Those charities that appeared in both the Excel file and in the Stata file were then regarded as 'clean'. The name recorded in the Master List file is the homogenized name of each charity. If a charity remained, that is it did not match up, it meant that it had either (i) not been recognized and cleaned, (ii) not been cleaned properly (e.g. there was a typo), (iii)) was not in the Master List, or (iv) was spelled incorrectly in the Master List or Stata file. This allowed us to catch nearly imperceptible spelling variations (e.g. an extra space) and to verify that the names in the master list and the names in the cleaned Stata file were in fact the same. (The number of charities in the Master list matches the number of charities in the cleaned Stata file: 762.)

\section{Cleaning of years}

The year to which the data for a charity recorded in an edition of Charity Trends was cleaned as follows.

The variable year_end in the CAF files was a string of the form mm/yy (e.g. 06/97). It was converted into two numeric variables, year_end_month, indicating the month in which a charity's financial year ended, and year_end_year, indicating the year. The variable year_end_month was not always a number from 1 to 12 . There were 78 cases of the month being a number greater than 12. In these cases the surrounding years were used to identify the correct end of the financial year.

When this cleaning was complete, it became apparent that on occasion the same data were present for a charity in successive issues of Charity Trends. If a charity failed to supply information in a timely manner to CAF, and it was clear that the charity belonged in the top 200/300/400/500 so that its absence from the report would appear strange, it was standard practice to publish again that charity's financial data from the previous year (indicating however the correct financial year end in the report). Any such duplicate observations were identified and dropped.

Once the year_end_year and year_end_month variables were clean and the duplicate observations dropped, the issue of assigning a year to each observation was addressed. A new variable (year_final) was generated following the rule that if year_end_month was less than or equal to 6, the observation was assigned to the previous year. Otherwise the observation was assigned to the current year.

If a charity changed its financial year from late in the year (after June) to early in the year (June or before), then we ended up with two observations of real data assigned to the same year. In such cases we dropped the second (later) observation. If a charity changed its financial year from early to late in the year, then a gap in the panel appeared. Such missing values, and other values missing for a single year, were imputed through linear interpolation. 
Table 1. Top 16 charities in overseas development sector, Charity Trends 2006

\begin{tabular}{lrrrr}
\hline \hline Charity & $\begin{array}{r}\text { Voluntary } \\
\text { Income } \\
(£ m)\end{array}$ & $\begin{array}{r}\text { In Top } \\
200 \text { in } \\
1978\end{array}$ & $\begin{array}{r}\text { Year } \\
\text { Founded }\end{array}$ & $\begin{array}{r}\text { End of year } \\
\text { covered }\end{array}$ \\
\hline & & & & \\
Oxfam & 176.6 & Yes & 1942 & Apr 2005 \\
Save the Children & 79.5 & Yes & 1919 & Mar 2005 \\
The Red Cross & 77.1 & Yes & 1863 & Dec 2004 \\
Christian Aid & 64.2 & Yes & 1964 & Mar 2005 \\
ActionAid & 57.6 & Yes & 1972 & Dec 2004 \\
Tearfund & 45.3 & No & 1968 & Mar 2005 \\
World Vision UK & 43.4 & No & 1950 & Sept 2005 \\
CAFOD & 39.6 & No & 1962 & Mar 2005 \\
World Emergency Relief & 34.8 & No & 1995 & Mar 2005 \\
Sight Savers & 30.7 & Yes & 1950 & Dec 2004 \\
Plan International & 25.8 & No & 1937 & Jun 2004 \\
UNICEF & 25.4 & No & 1956 & Dec 2004 \\
Islamic Relief & 20.1 & No & 1984 & Dec 2004 \\
Comic Relief & 18.4 & No & 1985 & Sep 2004 \\
Wateraid & 15.7 & No & 1981 & Mar 2005 \\
Médecins Sans Frontières & 10.4 & No & 1971 & Dec 2004 \\
TOTAL & 764.6 & & & \\
\hline \hline
\end{tabular}

Source: Charity Trends 2006

Notes: These charities are in the 'international' and 'religious international' categories defined by CAF. CAFOD is the Catholic Agency for Overseas Development. Voluntary income includes legacies in this table. 
Table 2. Breakdown of voluntary income in Charity Trends 2003

\begin{tabular}{lrrrr}
\hline \hline & \multicolumn{2}{c}{ Development } & \multicolumn{2}{c}{ Other causes } \\
& £s (m) & $\%$ & £s (m) & $\%$ \\
\hline Donations & 327 & 56.1 & 1,699 & 51.2 \\
Legacies & 68 & 11.6 & 991 & 29.9 \\
Donated goods & 78 & 13.4 & 292 & 8.8 \\
Fundraising & 108 & 18.5 & 289 & 8.7 \\
National Lottery & 2 & 0.4 & 46 & 1.4 \\
Total & 583 & 100.0 & 3,316 & 100.0 \\
\hline \hline
\end{tabular}

Source: Charity Trends 2003. The definition of 'development' is as used in the rest of the paper, i.e. including ‘international religious’ charities (and excluding St John’s Ambulance).

Table 3. Average annual growth rates for development charities, donations and legacies in real terms

\begin{tabular}{lrrrrr}
\hline \hline & $\begin{array}{r}1978- \\
1983\end{array}$ & $\begin{array}{r}1983- \\
1985\end{array}$ & $\begin{array}{r}1986- \\
1997\end{array}$ & $\begin{array}{r}1997- \\
2004\end{array}$ & $\begin{array}{r}1978- \\
2004\end{array}$ \\
\hline $\begin{array}{l}\text { Donations of development charities } \\
\text { in the top 200 }\end{array}$ & 12.6 & 51.9 & -0.2 & 7.0 & 7.5 \\
$\begin{array}{l}\text { Donations of the top 14 } \\
\text { development charities }\end{array}$ & 12.0 & 50.3 & -1.3 & 9.1 & 7.3 \\
$\begin{array}{l}\text { Legacies received by development } \\
\text { charities in the top 200 }\end{array}$ & 6.3 & 14.2 & 6.2 & 5.0 & 6.5 \\
\hline \hline
\end{tabular}

Notes: 'Donations' are defined for the purpose of this table as total voluntary income less legacies and hence include donated goods to charity shops, fundraising and grants from the National Lottery. Donations are in 2007 prices and the growth rates are of these constant price values. 
Table 4. The 14 development charities in the top 200 in 1978, donations

\begin{tabular}{|c|c|c|c|}
\hline \multirow{2}{*}{ Charity } & \multicolumn{2}{|c|}{ Donations } & \multirow{2}{*}{$\begin{array}{r}\text { Average } \\
\text { annual } \\
\text { growth rate } \\
\% \\
\end{array}$} \\
\hline & 1978 & 2004 & \\
\hline Oxfam & 27.6 & 180.0 & 7.5 \\
\hline Christian Aid & 18.0 & 62.1 & 4.9 \\
\hline Save the Children & 17.8 & 69.1 & 5.4 \\
\hline Red Cross & 11.2 & 65.3 & 7.0 \\
\hline Tearfund & 8.2 & 46.8 & 6.9 \\
\hline Leprosy Mission & 6.8 & $(2001)$ & 1.9 \\
\hline ActionAid & 6.2 & 61.9 & 9.2 \\
\hline Sightsavers & 3.5 & 27.0 & 8.2 \\
\hline LEPRA & 2.1 & 4.3 & 2.9 \\
\hline Sudan United Mission & 1.0 & (1984) & 2.3 \\
\hline Co-Workers of Mother Theresa & 1.0 & (1993) & -5.6 \\
\hline Voluntary Service Overseas & 0.9 & 4.6 & 6.4 \\
\hline UNICEF & 0.7 & 25.8 & 14.7 \\
\hline War on Want & 0.5 & $(2000)$ & 4.1 \\
\hline
\end{tabular}

Notes: Donations defined as in Table 3. Years in parentheses indicate the year that a charity last appeared in the CAF rankings. Donations are in 2007 prices. 
Table 5. Average annual growth rates of different charity sectors in the top 200

\begin{tabular}{lrrrrr}
\hline \hline & $1978-1983$ & $1983-1985$ & $1985-1997$ & $1997-2004$ & $1978-2004$ \\
\hline Medical & 5.8 & 2.2 & 11.3 & 7.0 & 8.3 \\
Disabled & 4.0 & 1.3 & 4.3 & 0.6 & 3.0 \\
Children & 3.3 & 21.2 & 6.0 & 3.5 & 5.8 \\
Religious & 3.9 & 5.1 & 3.9 & 6.1 & 4.6 \\
Elderly & 3.1 & -1.3 & 6.6 & -3.7 & 2.4 \\
Animals & -7.9 & -7.9 & 19.2 & 10.3 & 8.9 \\
Other & 11.3 & 6.8 & 6.3 & 0.7 & 5.7 \\
Environment \& heritage & 16.2 & -10.3 & 8.5 & 2.1 & 6.6 \\
All non-development & 5.7 & 3.4 & 7.3 & 3.8 & 5.7 \\
Development & 12.6 & 51.9 & -0.2 & 7.0 & 7.5 \\
\hline \hline
\end{tabular}

Notes: Donations defined as in Table 3. Growth rates are in real terms. 
Figure 1. UK Official Development Assistance (ODA), Es billion 2007-8 prices

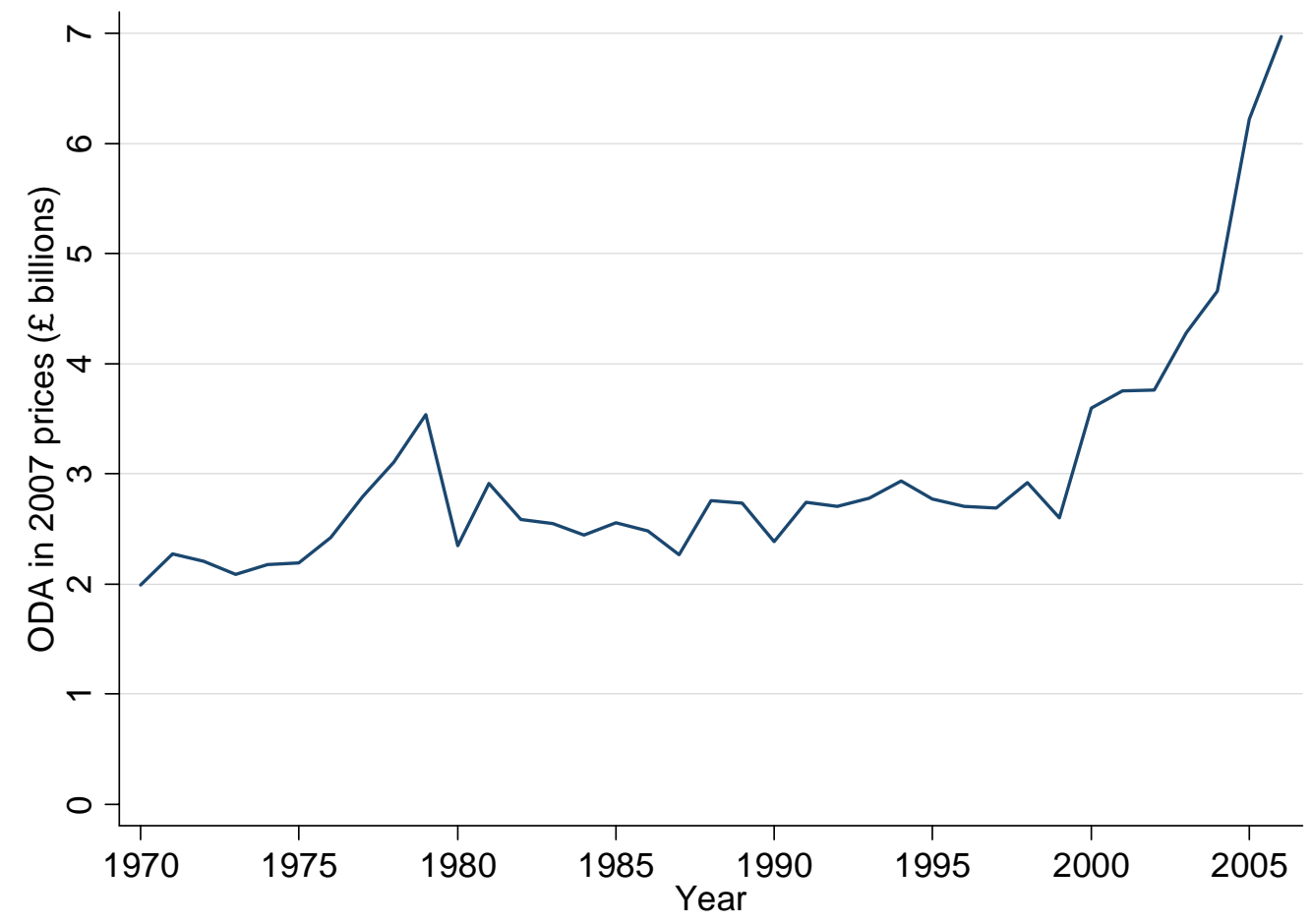

Source: ODA figures are from Statistics on International Development 2007, Table 7

http://www.dfid.gov.uk/pubs/files/sid2007/section2.asp. (The figures in the text for spending on ODA as a percentage of GDP are taken from the same website.) The data are put into 2007-8 prices using the GDP deflator at market prices from available from: http://www.hm-treasury.gov.uk/data_gdp_fig.htm. 
Figure 2. The number of development charities among the largest fundraisers

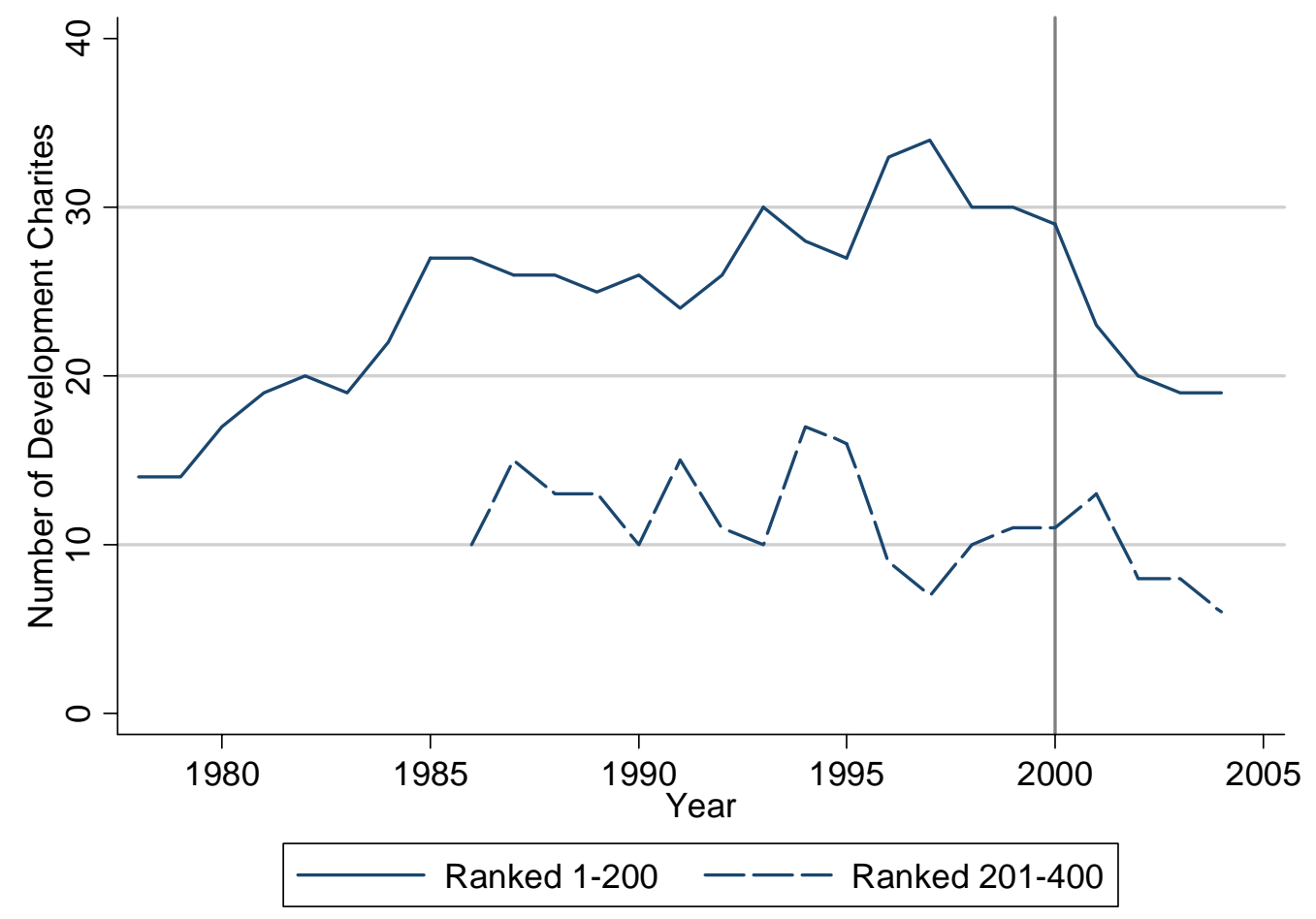


Figure 3. Distribution of ranks for development charities, 1991-2004

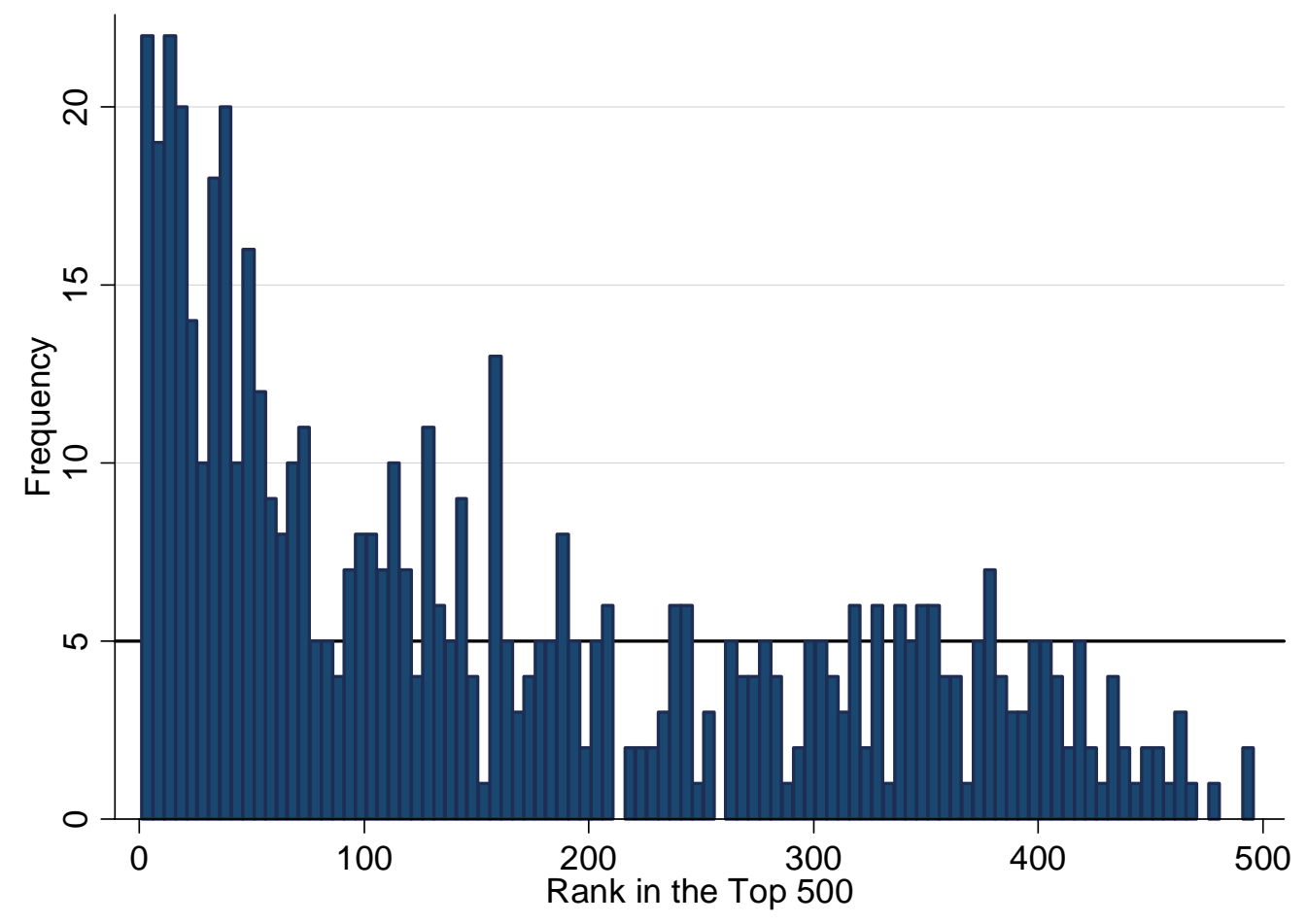

Notes: Each bar relates to five ranks e.g. the first bar shows the number of times development charities were ranked in the first five places among the top 500 charities ranked by donations over the period 1991 to 2004. Donations defined as in Table 3. 
Figure 4. Total donations (at constant prices) to development charities among the largest fundraisers (log scale)

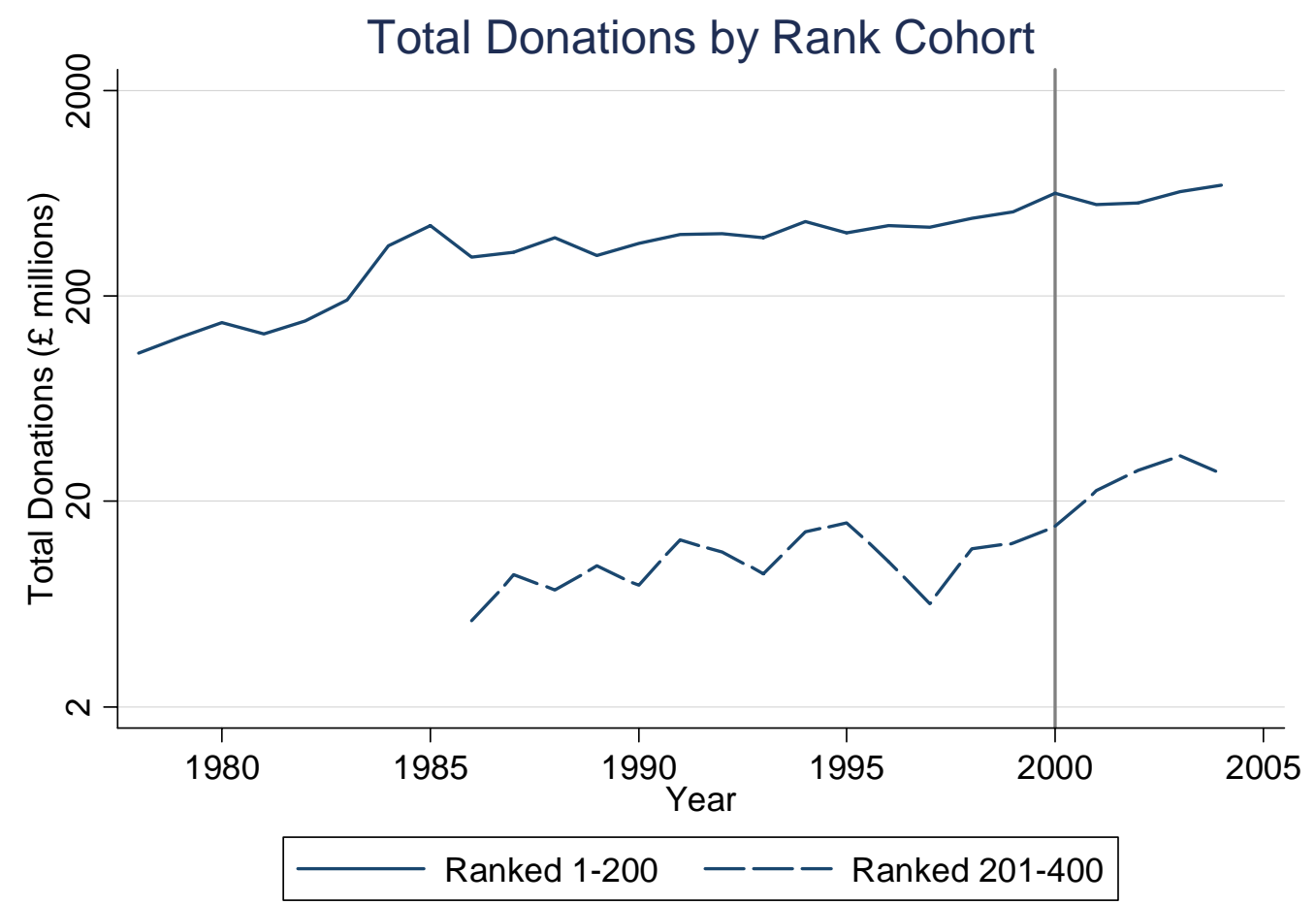

Notes: Donations defined as in Table 3. 
Figure 5. Total donations (at constant prices) of (a) all development charities in the top 200 and (b) the top 14 charities

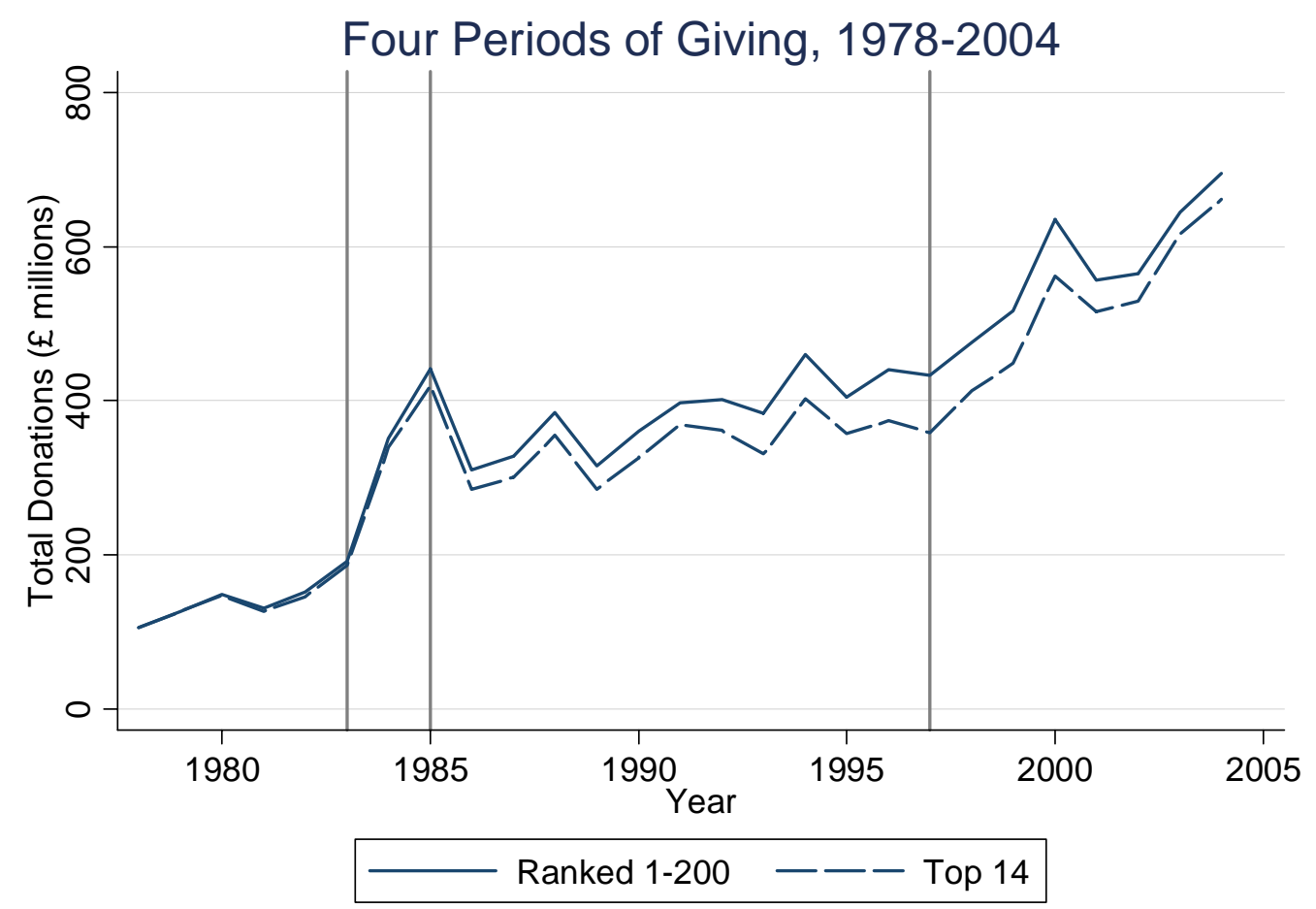

Notes: Donations defined as in Table 3. 
Figure 6. UK Donations to development charities and UK residents' spending on visits abroad (at constant prices)

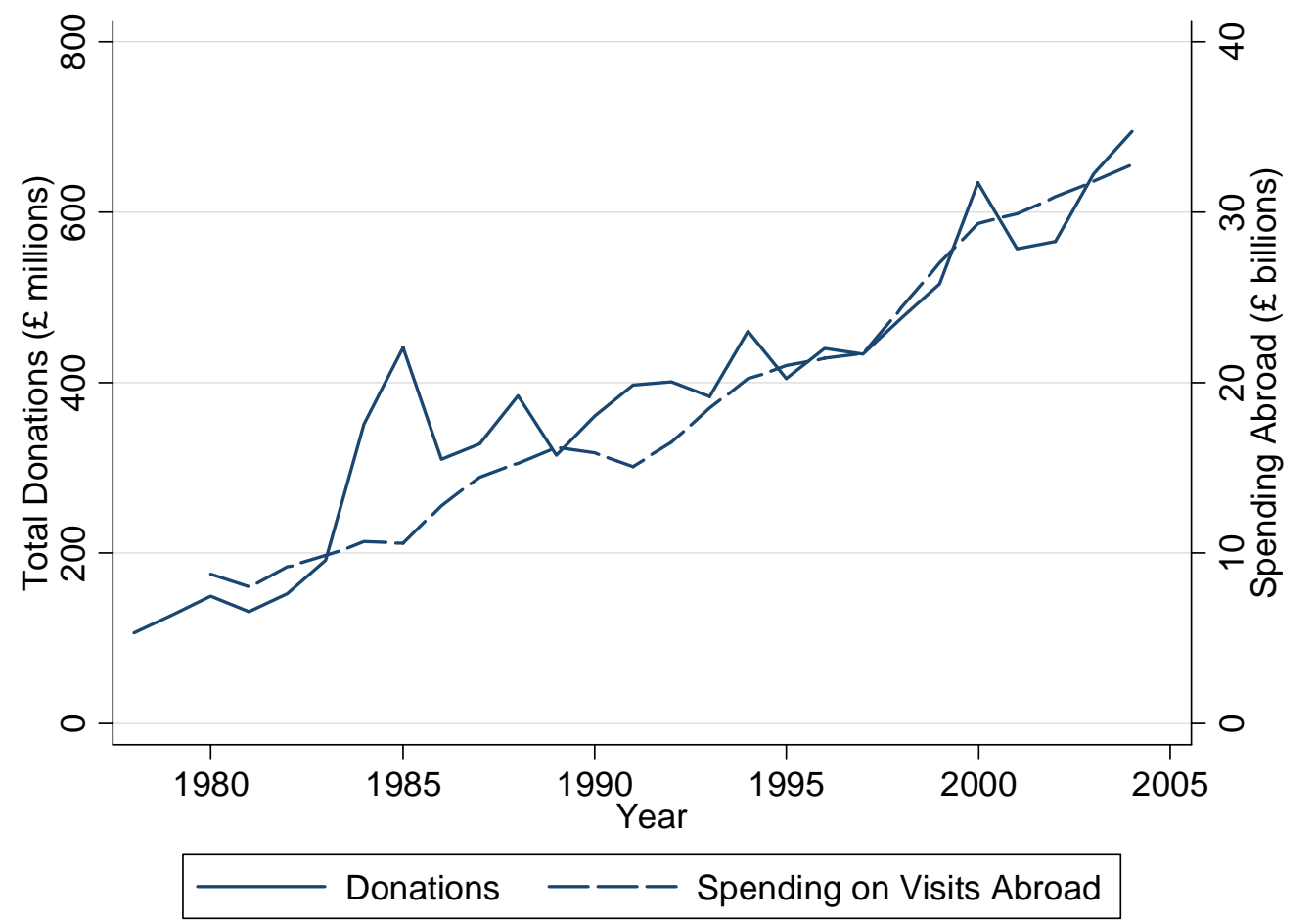

Notes: Donations defined as in Table 3. Figures on spending abroad taken from Travel Trends 2006 (for 1982-2004) and Travel Trends 2000 (1980-81), Table 1.02. As for donations, the spending figures are put into 2007 prices using the RPI. 
Figure 7. Legacies (at constant prices) received by development charities in the Top 200

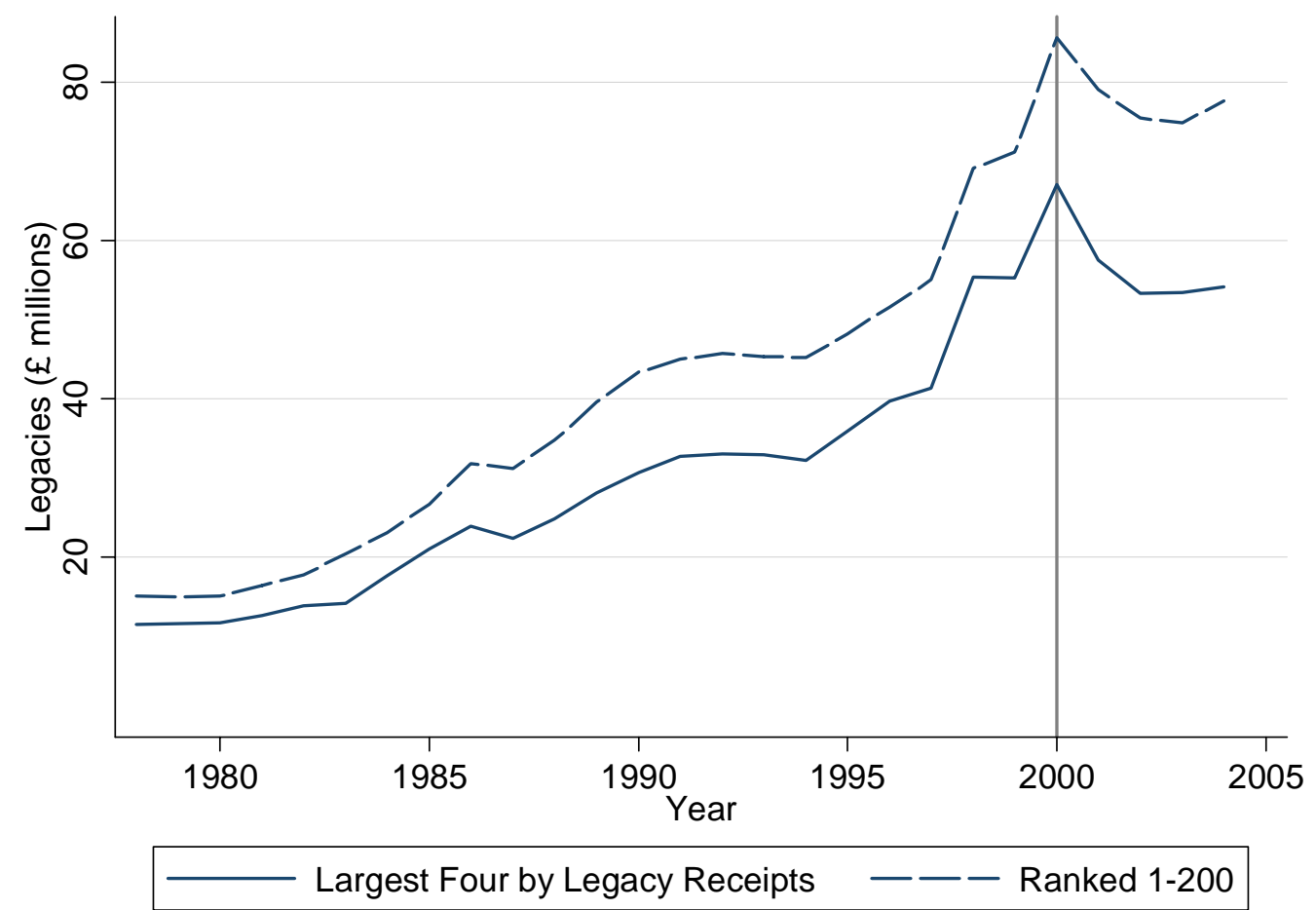

Notes: Legacies are in 2007 prices. 
Figure 8. Donations (at constant prices) made to large development charities a)

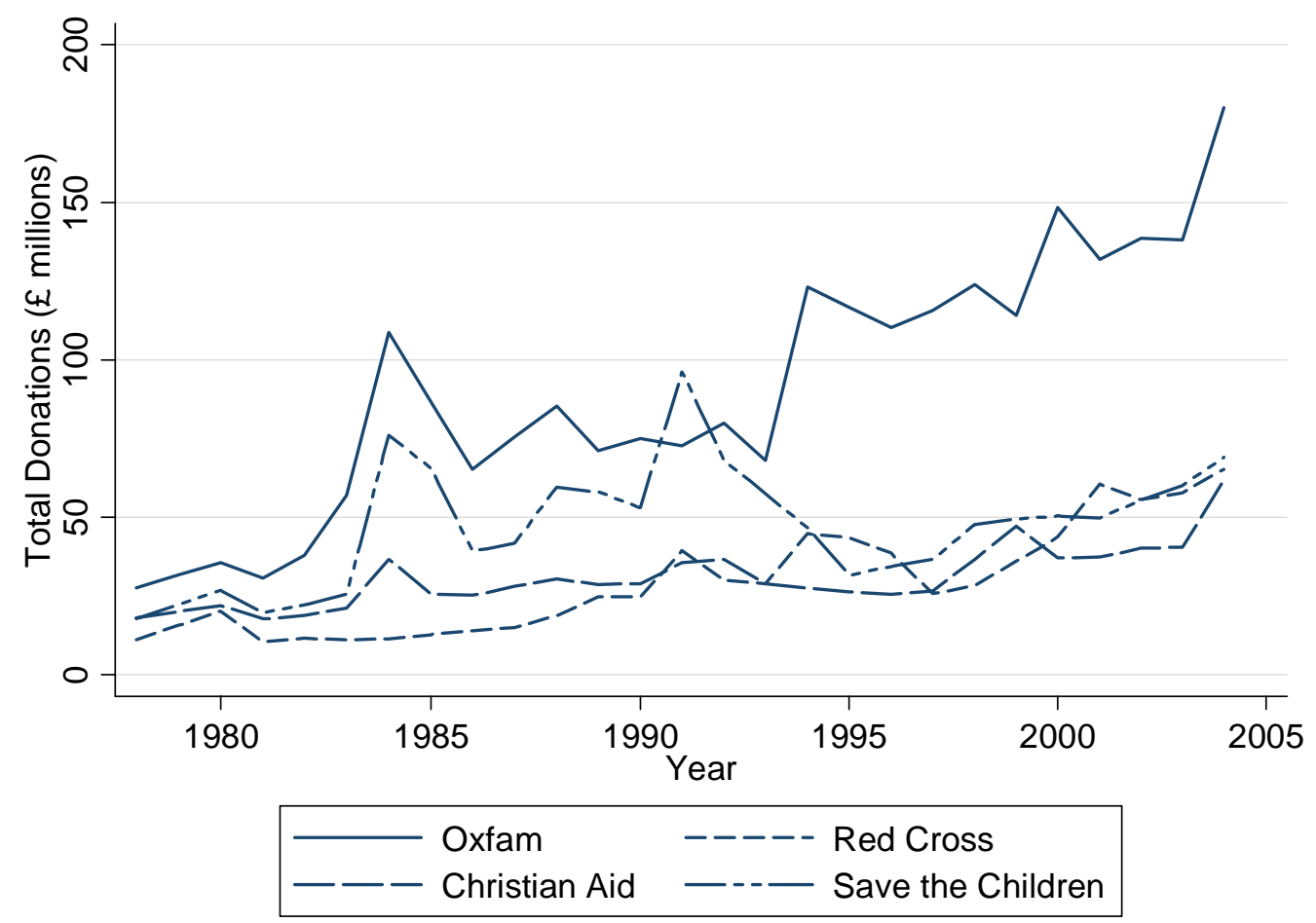

b)

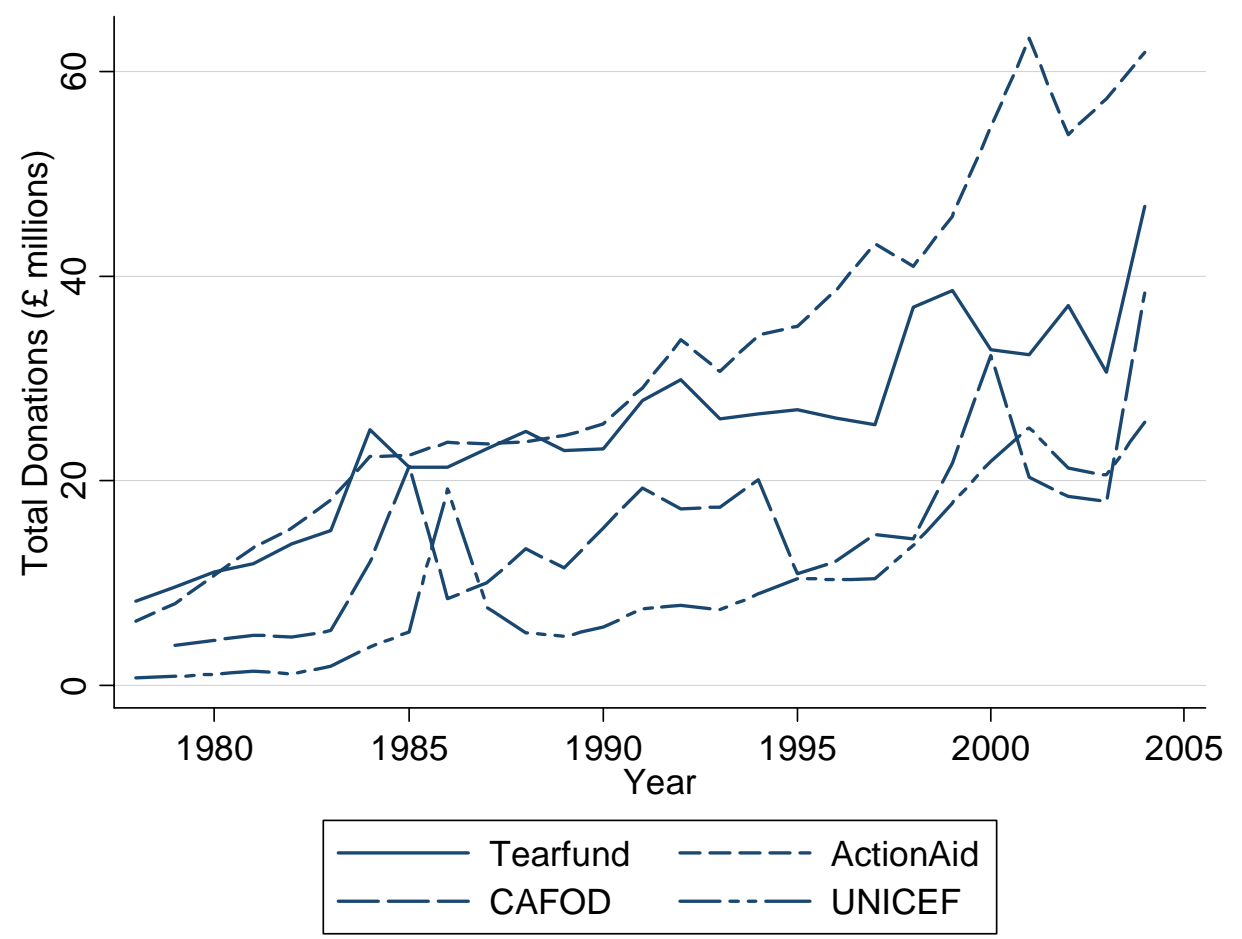

Notes: Donations defined as in Table 3. 
Figure 9. Share of donations to development charities in the top 200 received by charities founded after 1978 (percent)

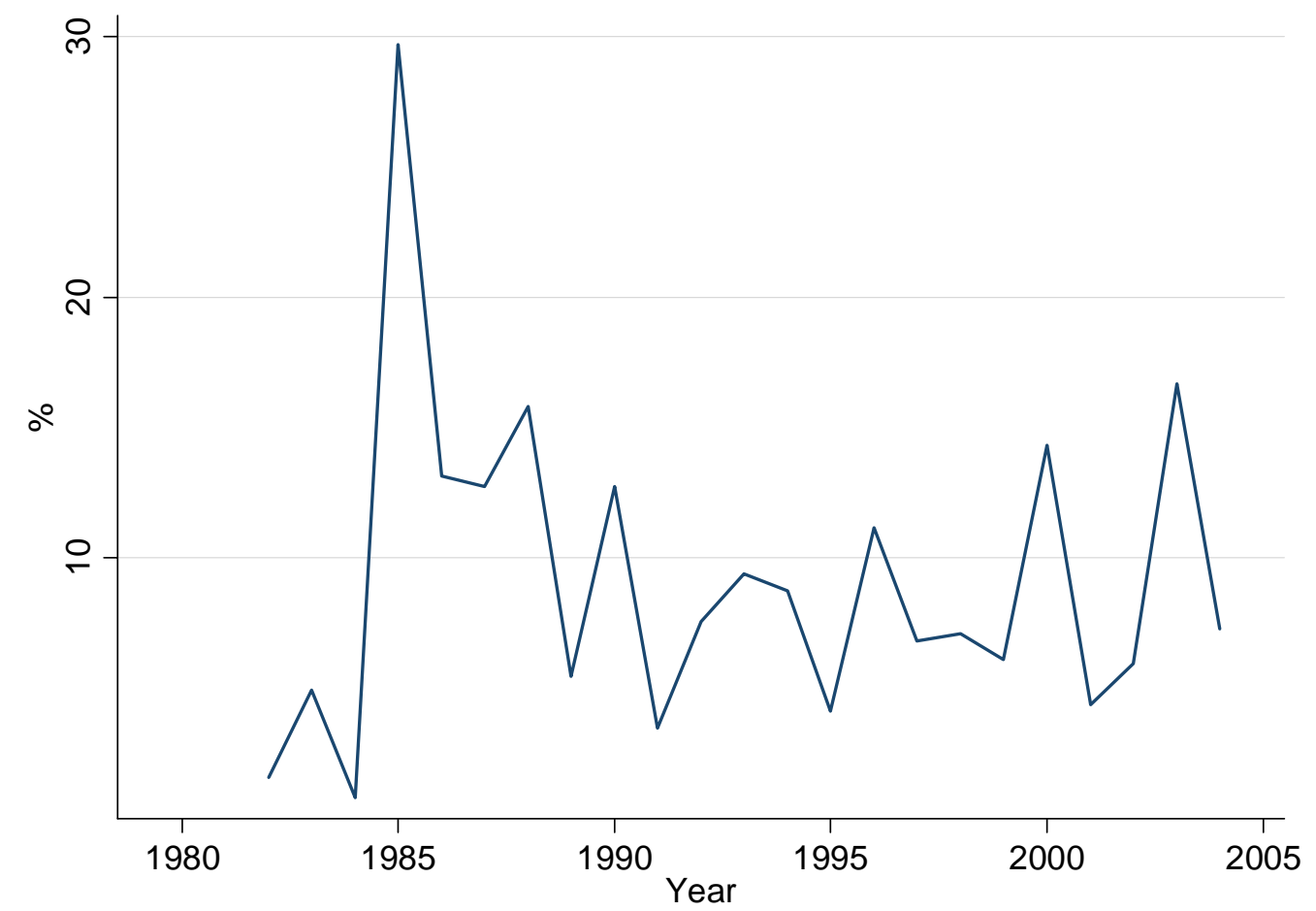

Notes: Donations defined as in Table 3. 
Figure 10. Four-charity concentration ratio of donations and legacies for development charities in the top 200 (percent)

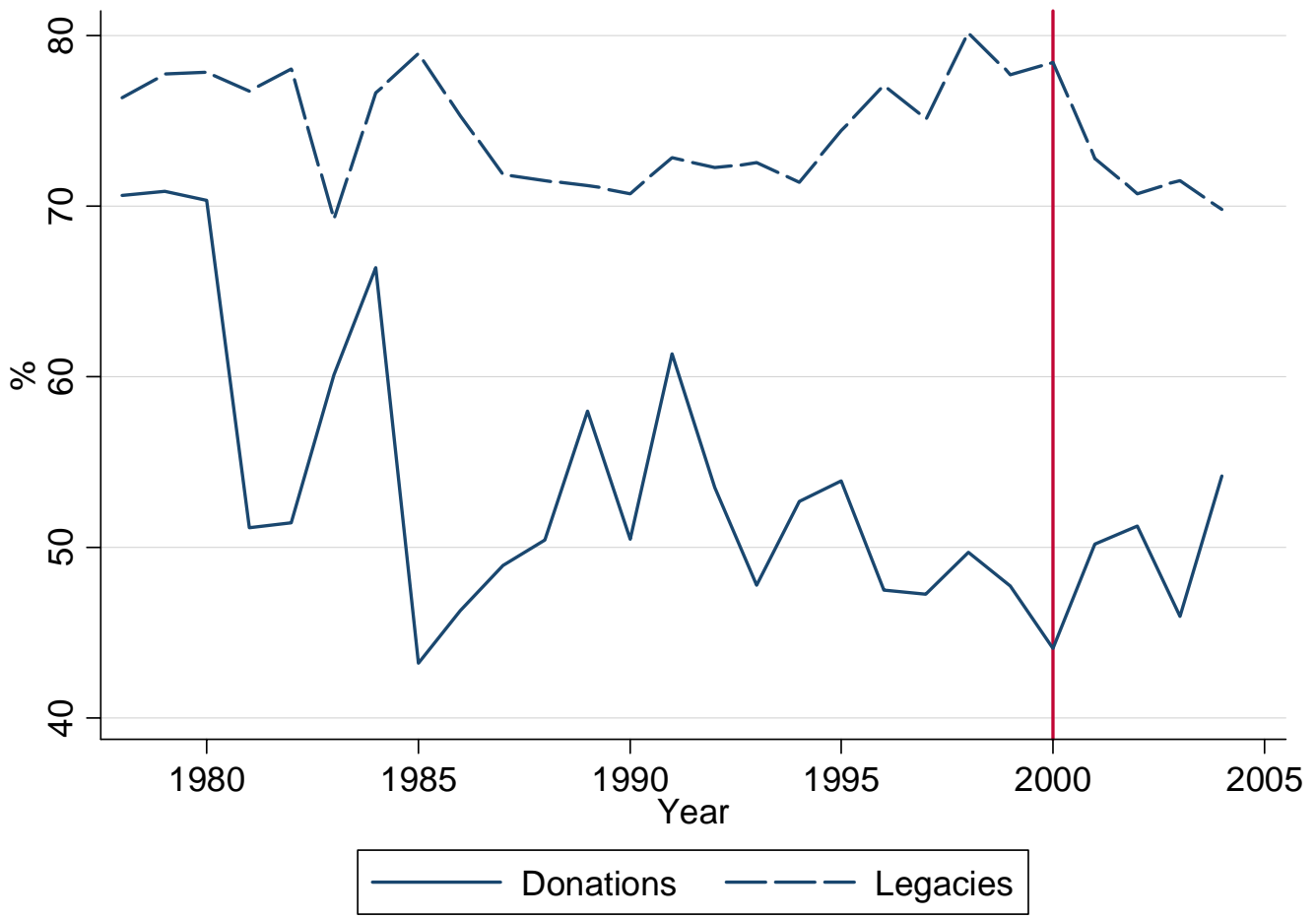

Notes: The graph shows the percent share of all donations that are received by the four charities with the most donations each year and the percent share of all legacies that are received by the four charities with the most legacies each year. In each case the base includes donations or legacies going to all development charities in the 200 largest recipients of donations or legacies. Donations defined as in Table 3. 
Figure 11. Total donations (at constant prices) to all development charities and to all other charities in the top 200 (log scale)

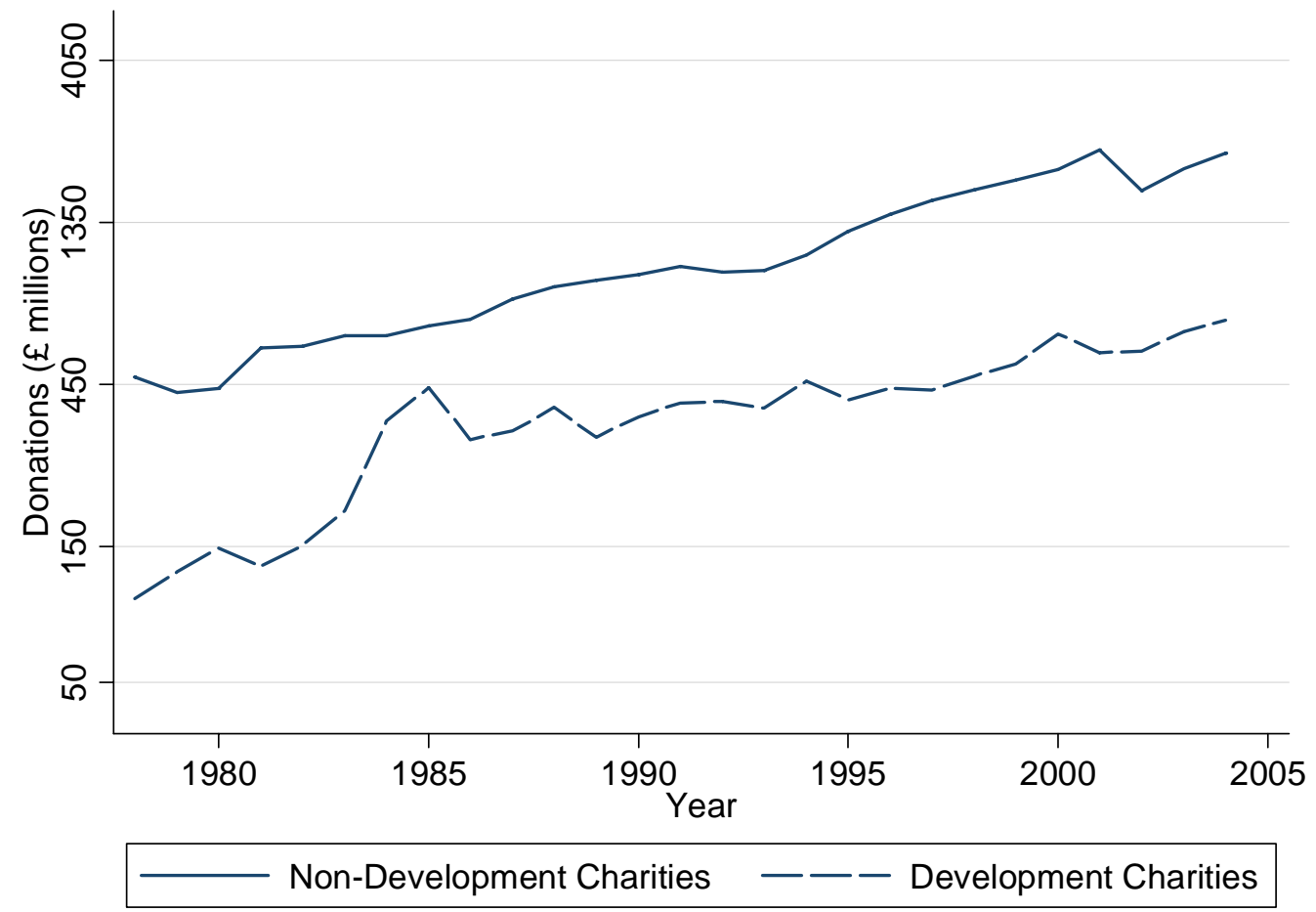

Notes: Donations defined as in Table 3. 
Figure 12. Two sources of data on government grants for development, 19812004 (at constant prices)

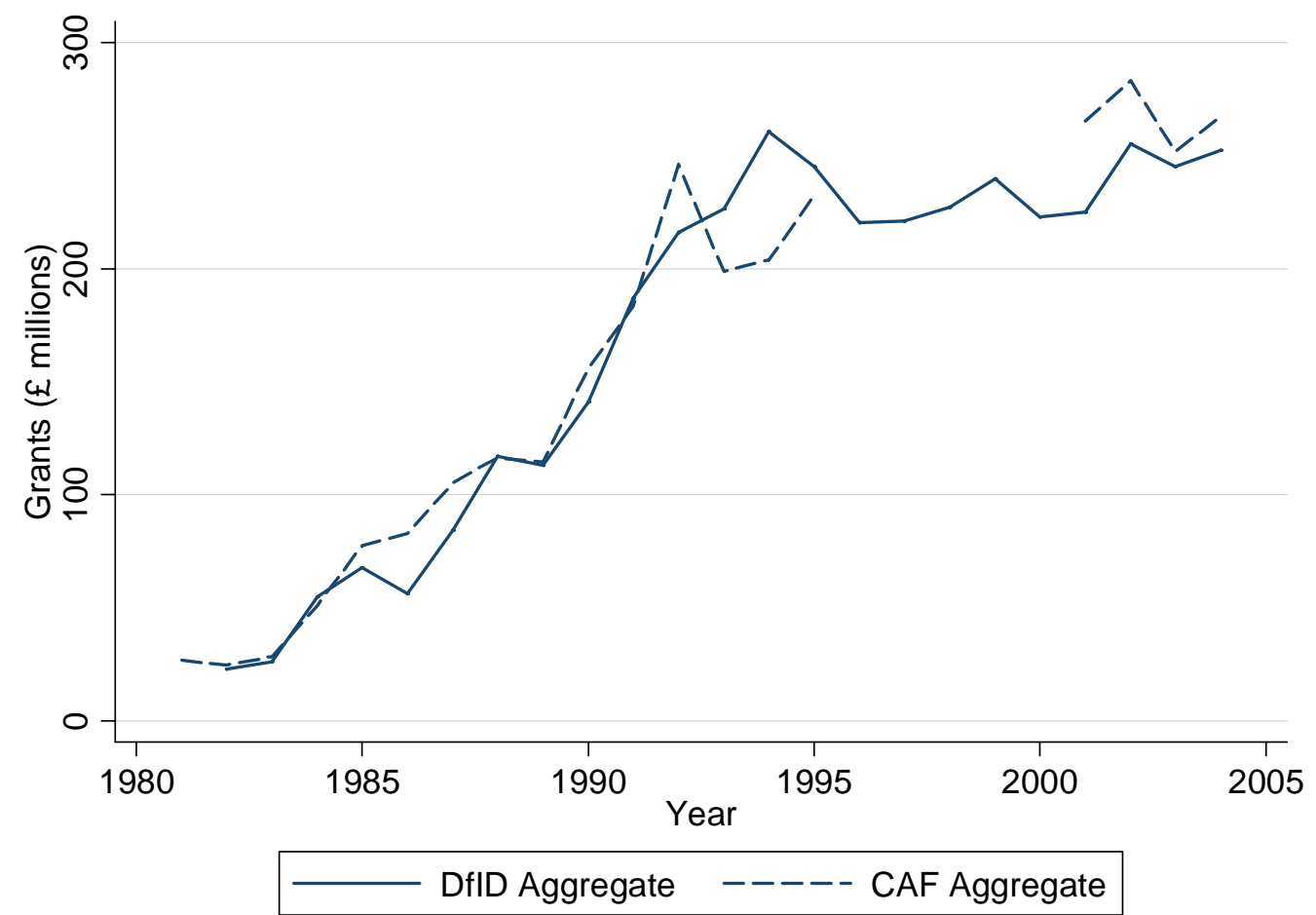

Notes: The DfID aggregate is from data kindly supplied by Ian Mocroft and and published in answers to Parliamentary Questions to 1993 and in Statistics on International Development from 1993. (Both series have been put into 2007 prices using the RPI.) 